\title{
Endocrine Disruptors in Food: Impact on Gut Microbiota and Metabolic Diseases
}

\author{
Yolanda Gálvez-Ontiveros ${ }^{1}$, Sara Páez ${ }^{1}$, Celia Monteagudo ${ }^{1,2, * \mathbb{D}}$ and Ana Rivas ${ }^{1,2}$ (D) \\ 1 Department of Nutrition and Food Science, University of Granada, 18071 Granada, Spain; \\ yolandagalvez@correo.ugr.es (Y.G.-O.); saripaez@correo.ugr.es (S.P.); amrivas@ugr.es (A.R.) \\ 2 Instituto de Investigación Biosanitaria Ibs.Granada, Complejo Hospitalario Universitario de Granada, \\ 18014 Granada, Spain \\ * Correspondence: celiams@ugr.es; Tel.: +34-958-242-841; Fax: +34-958-249-577
}

Received: 29 February 2020; Accepted: 14 April 2020; Published: 21 April 2020

check for updates

\begin{abstract}
Endocrine disruptors (EDCs) have been associated with the increased incidence of metabolic disorders. In this work, we conducted a systematic review of the literature in order to identify the current knowledge of the interactions between EDCs in food, the gut microbiota, and metabolic disorders in order to shed light on this complex triad. Exposure to EDCs induces a series of changes including microbial dysbiosis and the induction of xenobiotic pathways and associated genes, enzymes, and metabolites involved in EDC metabolism. The products and by-products released following the microbial metabolism of EDCs can be taken up by the host; therefore, changes in the composition of the microbiota and in the production of microbial metabolites could have a major impact on host metabolism and the development of diseases. The remediation of EDC-induced changes in the gut microbiota might represent an alternative course for the treatment and prevention of metabolic diseases.
\end{abstract}

Keywords: endocrine disrupters; food; gut microbiota; metabolic diseases

\section{Introduction}

It has been widely reported that some exogenous compounds can interfere with the function of the endocrine system in the body. According to the Endocrine Society, an Endocrine Disrupting Chemical (EDC) is "an exogenous [non-natural] chemical, or mixture of chemicals, that interferes with any aspect of hormone action" [1,2]. In this respect, the main source of human exposure to EDCs is food intake. These chemicals might pass into the food chain directly when they are used as pesticides, or they might be released from food packaging containing metals, bisphenol A, or phthalates. In addition, some plant-based compounds (the so-called phytoestrogens) found in dietary supplements also exhibit endocrine disrupting potential [3].

Endocrine disruptors have been associated with the increased incidence of metabolic disorders. It has been proposed that EDCs may increase the susceptibility to these disorders by altering the adipose tissue, pancreas, liver, gastrointestinal tract, muscle, and brain homeostatic and hedonic pathways [4]. However, few studies have reported that the effects of EDCs on the gut microbiota can increase the risk of metabolic disorders such as obesity and diabetes $[5,6]$.

Emerging evidence suggests interactions between EDCs and the microbiome, which may affect host health. A key triad between exposure to EDCs, the host genotype and phenotypic responses, and the gut microbiome has been suggested [7]. Exposure to EDCs has been shown to disrupt the microbiome, which may result in dysbiosis and the induction of pathways related to xenobiotics, microbiome-associated genes, enzymes, and the production of metabolites, which may play a crucial role in EDC biotransformation [8]. The products and by-products released following the microbial 
metabolism of EDCs can be taken up by the host, therefore having an impact on host health and on the development of diseases. In addition, the gut microbiota can modify the EDC profiles through different plausible mechanisms. Microbial enzymes (esterases, thiolases, azoreductases, nitroreductases, $\beta$-glucoronidases, methylases, sulfatases, lipases, and $\beta$-lyases) can be used to metabolize different types of EDC [9]. Dysbiosis and a reduced diversity of the gut microbiota may cause a reduction in the enzymatic activity, which in turn could result in a decreased metabolization of EDCs to their circulating, active forms, thereby reducing the potential EDC toxicity to the host.

In this work, we conduct a systematic review of the literature in order to identify the current knowledge regarding the interactions between the EDCs in food, thye gut microbiota and metabolic disorders, in order to shed light on this complex triad.

\section{Methods}

The PubMed and Web of Sciences databases were searched to identify the relevant studies. The following keywords were used: "Gut microbiota", "Diet”, "Obesity”, "Diabetes", "Bisphenol A", "Bisphenol A analogs", "Microbiota", "Pesticides", "Parabens", "Polychlorinated biphenyls", "Phytoestrogens", "Metals", "Cadmium", "Arsenic", "Lead", "Phthalates", "Triclosan", and "Triclocarban". Data published between 2006 and 2020 were considered.

The literature review was conducted in compliance with the recommendations provided in the Preferred Reporting Items for Systematic Reviews and Meta-Analyses (PRISMA). Figure 1 shows the PRISMA flow diagram that maps out the number of studies identified, those included and excluded, and the reasons for exclusion ((a) papers not written in the English language, (b) no outcome of interest, and (c) not related to the subject of the study). A total of 107 studies were included for analysis [10].

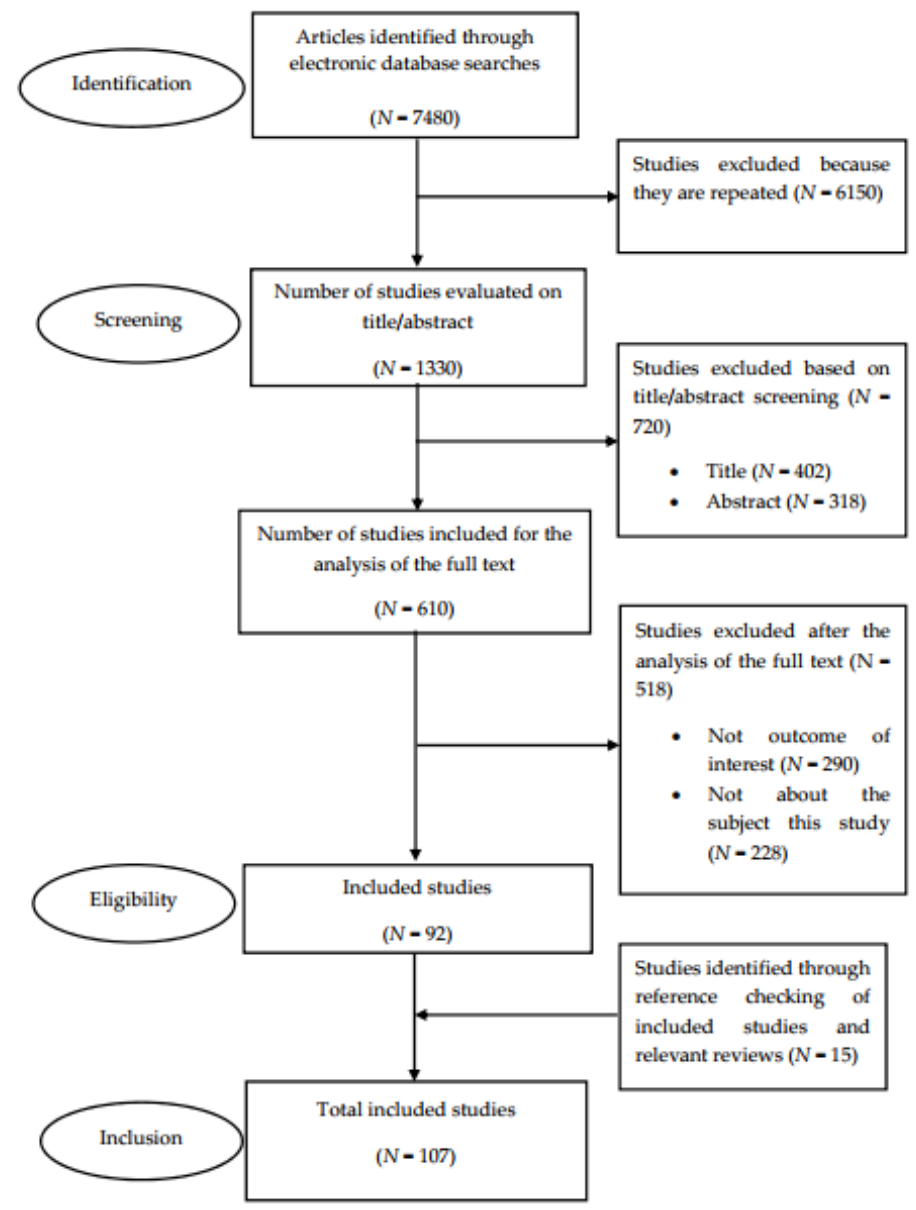

Figure 1. A flow diagram of the literature search. 


\section{Results and Discussion}

\subsection{The Gut Microbiota in Health and Metabolic Diseases}

A remarkable amount of evidence has emerged in recent years that strongly suggests that an essential role is played by the human microbiota in health and disease development via several mechanisms [11]. Variations in gut microbiota composition are considered to be physiological from the perspective of healthy gut microbiota, and these changes are related to age; sex; and external factors such as dietary habits, exercise, and antibiotic use. Indeed, dysbiosis, defined as the alteration of gut microbiota communities, is often related to health disorders.

Firmicutes and Bacteroidetes are the two primary phyla in gut microbiota, accounting for 90\% of the total composition [12]. Other phyla include Actinobacteria, Proteobacteria, Fusobacteria, and Verrucomicrobia [13]. The Firmicutes phylum is composed of more than 200 different genera such as Enterococcus, Lactobacillus, Ruminicoccus, Bacillus, and Clostridium. The phylum Bacteroidetes is dominated by the genera Prevotella and Bacteroides. The Actinobacteria phylum is comparably less abundant and mostly represented by the Bifidobacterium genus [13].

In recent years, research has demonstrated that gut microbiota could play an important role in the pathophysiology of metabolic disorders, specifically in obesity and diabetes [14]. Animal studies have shown that obesity is related to changes in the gut microbiota composition, including a reduction in species variety and alterations in the genes involved in metabolism. By contrast, data related to the human microbiota are more variable [13]. When fed with a similar diet, the comparison of the gut microbiota of genetically obese (ob/ob) mice with that of lean mice showed a greater abundance of Firmicutes and lower relative abundance of Bacteriodetes (50\%) in obese mice [15]. These changes in the microbiota have also been found in different human studies [16,17]. Moreover, low relative amounts of Bifidobacterium vulgatus and high abundances of Lactobacillus spp. are detected in the microbiota of obese children [18]. Other studies have reported on the relationship between the Proteobacteria phylum and obesity, by the identification of pro-inflammatory molecules such as lipopolysaccharides and increased fat storage in the host [19]. In addition, higher abundances of Rikenellaceae and Ruminococcaceae have been revealed in leptin-resistant obese (leptin-promoting satiety) and diabetic (db/db) mice compared with in the lean members of the same litter [20]. Furthermore, other authors have demonstrated a relationship between Desulfovibrionaceae growth induction, obesity, and type 2 diabetes (T2D) [21,22].

There is also cumulative evidence from human and animal studies of an association between the development of diabetes and the existence of changes in the gut microbiota composition. Larsen et al. (2010) [23] showed that the Firmicutes phylum and Clostridia class decreased significantly in humans with T2D compared to in the healthy control group. Likewise, the $\beta$-Proteobacteria class increased in diabetics compared to in the control group and was positively associated with plasma glucose levels. Murri et al. (2013) [24] reported increased Veillonella, Bacteroidetes, and Clostridium spp.- -along with a decrease in Blautia, Lactobacillus, Prevotella, and Bifidobacterium - in children with diabetes type 1 diabetes (T1D) compared to in the healthy control group.

\subsection{Role of EDCs in the Microbiota}

Tables 1-3 provide information concerning the effect of endocrine disruptors on gut microbiota in vitro, in animals, and in human studies.

\subsubsection{BPA and Analogs}

Bisphenol A (BPA) is an environmental chemical widely used in industry for the manufacture of polycarbonate plastics and epoxy resins, with well-known endocrine disrupting activity $[25,26]$. The public concern about the safety of BPA has resulted in the imposition of a ban on its use in some products and the emerging market entry of BPA analogs such as bisphenol S (BPS), bisphenol F (BPF), bisphenol AF (BPAF), and bisphenol B (BPB). However, their structural similarity to BPA has also raised concerns about their endocrine disrupting potential. Several studies have reported on the association 
of BPA and BPA analogs with an increased risk of developing metabolic diseases such as obesity $[25,27]$. However, this association is not well demonstrated, and it is challenging to find evidence for direct causality between BPA and analog exposure and metabolic diseases using epidemiological studies.

Wang et al. (2018) [28] studied the changes in metabolism and accessibility of BPA in different parts of the gastrointestinal tract using an in vitro Simulator of the Human Intestinal Microbial Ecosystem (SHIME) model. Three different BPA concentrations were investigated, which provided information regarding an extensive range of BPA daily intake values, from the human relevant exposure dose (25 $\mu \mathrm{g} / \mathrm{L}$ ) and the EPA (Environmental Protection Agency) reference dose $(250 \mu \mathrm{g} / \mathrm{L})$, to the $1 \%$ lowest observed adverse effect level $(2500 \mu \mathrm{g} / \mathrm{L})$ [28]. The toxicity of BPA, in terms of the effects on the hepatic gene expression profiles, was compared with that of the SHIME effluents, using the human hepatocellular carcinoma (HEPG2) cell line. The findings showed that BPA exposure modified the microbial composition of the colon, increasing the amount of microbes in the ascending, transverse, and descending colon. The upregulation of BPA-degrading bacteria, such as Microbacterium and Alcaligenes, was also reported.

Exposure to BPA and BPA analogs in animal models such as rodents, zebrafish, rabbits, and dogs can affect the gut microbiota and have an impact on the development of metabolic diseases. Some studies have reported that there is a sexual dysmorphic effect [6,29-33].

$\mathrm{Xu}$ et al. (2019) [33] determined the impact of BPA exposure on the development of T1D and the involvement of the host immune system and gut microbiota in a model of non-obese diabetic (NOD) mice. Adult male and female NOD mice were orally exposed to BPA at environmentally relevant doses ( 30 or $300 \mu \mathrm{g} / \mathrm{kg}$ ). These doses were selected because they had previously been shown to modify the immune system and to be relevant for human exposure (30 BPA/kg body weight (bw) is within the range of human exposure levels, and $300 \mathrm{BPA} / \mathrm{kg}$ bw is also appropriate for human exposure levels based on BPA concentrations in human blood) [34]. In addition, the current EPA reference dose is $50 \mu \mathrm{g} / \mathrm{kg} /$ day. However, exposure to low-dose BPA also seems to have harmful effects, and as a consequence, after careful examination, the European Food Safety Authority (ESFA) has lowered the total dietary intake to $4 \mu \mathrm{g} / \mathrm{kg}$ bw/day. 
Table 1. Effects of endocrine disruptors on the gut microbiota in in vitro assays.

\begin{tabular}{|c|c|c|c|c|c|c|c|}
\hline References & Compound & Dose Exposure & $\begin{array}{l}\text { Justification of } \\
\text { Exposure Dose }\end{array}$ & $\begin{array}{c}\text { Species Strain } \\
\text { Mode }\end{array}$ & Methods & Outcomes & Conclusions \\
\hline $\begin{array}{l}\text { Van de Wiele et al. } \\
\text { (2010) [35] }\end{array}$ & Metal (Arsenic) & $\begin{array}{c}10 \mu \mathrm{g} \\
\text { methylarsenical/g } \\
\text { biomass/hr and } 28 \mu \mathrm{g} \\
\text { as-contaminated } \\
\text { soils/g biomass/hr }\end{array}$ & $\begin{array}{l}\text { Concentrations } \\
\text { detected in arsenic } \\
\text { contaminated soils in } \\
\text { urban areas of the } \\
\text { EEUU }\end{array}$ & $\begin{array}{l}\text { Strains isolated } \\
\text { from human feces }\end{array}$ & $\begin{array}{l}\text { HPLC; plasma } \\
\text { mass spectrometry }\end{array}$ & $\begin{array}{l}\text { High degree of methylation of } \\
\text { Methylarsenical and } \\
\text { As-contaminated soils in } \\
\text { colon digestion. }\end{array}$ & $\begin{array}{l}\text { Human microbiota has ability } \\
\text { to actively metabolize As into } \\
\text { methylated arsenicals and } \\
\text { thioarsenicals. }\end{array}$ \\
\hline $\begin{array}{l}\text { Wang et al. } \\
\text { (2018) [28] }\end{array}$ & ВРА & $\begin{array}{c}25 \mu \mathrm{g} / \mathrm{L}, 250 \mu \mathrm{g} / \mathrm{L} \\
\text { and } 2500 \mu \mathrm{g} / \mathrm{L}\end{array}$ & $\begin{array}{l}\text { High human relevant } \\
\text { exposure dose; } \\
\text { EPA reference dose; } \\
1 \% \text { lowest observed } \\
\text { adverse effect level }\end{array}$ & Humans & $\begin{array}{l}\text { In vitro SHIME, } \\
16 \mathrm{~S} \text { rRNA } \\
\text { gene sequencing, } \\
\text { and PCR }\end{array}$ & $\begin{array}{l}\text { BPA exposure decreased the } \\
\text { diversity of gut microbioma } \\
\text { (ascending colon and the } \\
\text { transverse colon). } \\
\text { Exposure to BPA of } 25 \mu \mathrm{g} / \mathrm{L} \\
\text { decreased diversity of gut } \\
\text { microbioma, but high-level } \\
\text { exposures }(250 \text { and } 2500 \mu \mathrm{g} / \mathrm{L} \text { ) } \\
\text { increased diversity } \\
\text { (descending colon). }\end{array}$ & $\begin{array}{l}\text { Exposure to BPA significantly } \\
\text { altered the microbiota and } \\
\text { increased the proportion of } \\
\text { shared microbes. }\end{array}$ \\
\hline $\begin{array}{l}\text { Hoffman et al. } \\
\text { (2019) [36] }\end{array}$ & PCB126 & 20 or $200 \mu \mathrm{M}$ & $\begin{array}{l}\text { Concentrations } \\
\text { physiologically relevant, } \\
\text { especially in heavily } \\
\text { exposed populations }\end{array}$ & C56BL6/J mice & $\begin{array}{l}16 \mathrm{~S} \text { rRNA gene } \\
\text { sequencing, PCR, } \\
\text { and HPLC }\end{array}$ & $\begin{array}{l}\text { Significant reduction in } \\
\text { bacterial growth after } \\
\text { exposure to high } \\
\text { concentrations of PCB } 126 \\
\text { compared to control. Not } \\
\text { significant reduction in } \\
\text { bacterial growth at PCB } \\
\text { concentrations below } 20 \mu \mathrm{M} \text {. }\end{array}$ & $\begin{array}{l}\text { Exposure to PCB126 can } \\
\text { contribute to alterations in } \\
\text { host metabolism through } \\
\text { mechanisms dependent on } \\
\text { the intestinal microbiota, } \\
\text { specifically through bacterial } \\
\text { fermentation or } \\
\text { membrane disruption. }\end{array}$ \\
\hline Lei et al. (2019) [37] & $\begin{array}{l}\text { Di (2-ethylhexyl) } \\
\text { phthalate }\end{array}$ & 10 or $100 \mu \mathrm{M}$ & $\begin{array}{l}\text { The concentration } \\
\text { mimics human } \\
\text { exposure during } \\
\text { adolescence by } \\
\text { continually exposing } \\
\text { mice to phthalate from } \\
\text { ages } 6 \text { to } 8 \text { weeks }\end{array}$ & C57BL/6J mice & $\begin{array}{c}\text { 16S rRNA gene } \\
\text { sequencing and a } \\
\text { triple-quadrupole } \\
\text { time-of-flight } \\
\text { instrument } \\
\text { coupled to a } \\
\text { binary pump } \\
\text { HPLC system }\end{array}$ & $\begin{array}{c}\text { Exposure of in vitro cecal } \\
\text { microbiota to di } \\
\text { (2-ethylhexyl)-phthalate } \\
\text { increased the abundance of } \\
\text { Alistipes, Paenibacillus, } \\
\text { and Lachnoclostridium. } \\
\text { Non-directed metabolomics } \\
\text { showed that di } \\
\text { (2-ethylhexyl)-phthalate } \\
\text { greatly altered the metabolite } \\
\text { profile in the culture. }\end{array}$ & $\begin{array}{l}\text { Di (2-ethylhexyl)-phthalate } \\
\text { can directly affect the } \\
\text { production of } \\
\text { bacterial metabolites related to } \\
\text { neurodevelopmental disorders. }\end{array}$ \\
\hline Joly et al. (2013) [38] & Chlorpyrifos & $1 \mathrm{mg} / \mathrm{kg} /$ day & NOAEL & Wistar rats & SHIME & $\begin{array}{l}\text { Exposure to chlorpyrifos } \\
\text { increased Bacteroides spp. and } \\
\text { Enterococcus spp. and reduced } \\
\text { Bifidobacterium spp. } \\
\text { and Lactobacillus spp. }\end{array}$ & $\begin{array}{l}\text { Chronic, low-dose exposure } \\
\text { to chlorpyrifos causes } \\
\text { gut dysbiosis. }\end{array}$ \\
\hline
\end{tabular}


Table 1. Cont.

\begin{tabular}{|c|c|c|c|c|c|c|c|}
\hline References & Compound & Dose Exposure & $\begin{array}{l}\text { Justification of } \\
\text { Exposure Dose }\end{array}$ & $\begin{array}{c}\text { Species Strain } \\
\text { Mode }\end{array}$ & Methods & Outcomes & Conclusions \\
\hline $\begin{array}{l}\text { Shehata et al. } \\
\text { (2013) [39] }\end{array}$ & Glyphosate & $\begin{array}{l}5.0,2.40,1.20,0.60,0.30 \\
0.15 \text {, and } 0.075 \mathrm{mg} / \mathrm{mL}\end{array}$ & $\begin{array}{l}\text { To determine the } \\
\text { minimal inhibitory } \\
\text { concentration }\end{array}$ & Chickens & $\begin{array}{l}\text { MALDI-TOF } \\
\text { MS analysis, } \\
\text { multiplex PCR }\end{array}$ & $\begin{array}{l}\text { In vitro exposure to } \\
\text { glyphosate showed resistance } \\
\text { to glyphosate in highly } \\
\text { pathogenic bacteria, but most } \\
\text { beneficial bacteria showed } \\
\text { susceptibility to glyphosate. }\end{array}$ & $\begin{array}{l}\text { Glyphosate exposure showed } \\
\text { differences in sensitivity } \\
\text { between pathogenic and } \\
\text { beneficial microbiota. } \\
\text { Ingestion of } \\
\text { glyphosate-contaminated } \\
\text { food reduced } \\
\text { the beneficial microbiota. }\end{array}$ \\
\hline $\begin{array}{l}\text { Ackermann et al. } \\
\quad(2015)[40]\end{array}$ & Glyphosate & $0,1,10$, and $100 \mu \mathrm{g} / \mathrm{mL}$ & $\begin{array}{c}\text { Concentrations lower } \\
\text { than NOAEL }\end{array}$ & Cows & $\begin{array}{l}\text { DAISYII-incubators, } \\
\text { FISH with 16S } \\
\text { rRNA/23S } \\
\text { rRNA-targeted }\end{array}$ & $\begin{array}{l}\text { Exposure to } 1 \text { and } 10 \mu \mathrm{g} / \mathrm{mL} \\
\text { glyphosate reduced } \\
\text { abundances of all species } \\
\text { except for Isotricha spp. } \\
\text { and Diplodinium spp. } \\
\text { Exposure to } 100 \mu \mathrm{g} / \mathrm{mL} \\
\text { glyphosate reduced } \\
\text { abundance of } \\
\text { Diplodinium spp. }\end{array}$ & $\begin{array}{l}\text { Glyphosate inhibits growth of } \\
\text { beneficial bacteria, } \\
\text { but increases the population } \\
\text { of pathogenic bacteria }\end{array}$ \\
\hline $\begin{array}{l}\text { Riede et al. } \\
\text { (2016) [41] }\end{array}$ & Glyphosate & 0.42 or $2.92 \mathrm{mg} / \mathrm{L}$ & $\begin{array}{l}\text { The low dose reflects } \\
\text { the estimated } \\
\text { maximum dietary } \\
\text { glyphosate intake of } \\
\text { dairy cattle, } \\
\text { according to } \\
\text { model assumptions. } \\
\text { The high dose is } \\
\text { higher than residues } \\
\text { found in the beef } \\
\text { cattle diet. }\end{array}$ & Cows & $\begin{array}{c}\text { RUSITEC } \\
\text { experiments, } \\
\text { LC-MS/MS } \\
\text { method, } 16 \mathrm{~S} \text { rRNA } \\
\text { gene sequencing, } \\
\text { and PCR }\end{array}$ & $\begin{array}{l}\text { Effects of glyphosate at } \\
\text { concentrations of } 0.42 \text { or } 2.92 \\
\text { mg/L. After the incubation } \\
\text { period only observed subtle } \\
\text { changes in the composition of } \\
\text { ruminal bacteria. }\end{array}$ & $\begin{array}{l}\text { No major changes were } \\
\text { observed due to Glyphosate } \\
\text { exposure to ruminal } \\
\text { metabolism or the } \\
\text { composition of bacterial } \\
\text { communities. }\end{array}$ \\
\hline
\end{tabular}

HPLC: high performance liquid chromatography; PCR: polymerase chain reaction; SHIME: simulator of the human intestinal microbial ecosystem; FISH: fluorescence in situ hybridation; MALDI-TOF MS: matrix-assisted laser desorption/ionization time-of-flight mass spectrometry; RUSITEC: rumen simulation technique; NOAEL: no observed adverse effects level. 
Table 2. Effects of endocrine disruptors on the animal microbiota.

\begin{tabular}{|c|c|c|c|c|c|c|c|}
\hline References & Compound & Dose Exposure & $\begin{array}{l}\text { Justification of } \\
\text { Exposure Dose }\end{array}$ & $\begin{array}{l}\text { Species Strain } \\
\text { Mode }\end{array}$ & Methods & Outcomes & Conclusions \\
\hline Ba et al. (2017) [42] & Metals (Cadmium) & $100 \mathrm{nM}$ & $\begin{array}{l}\text { Tolerable weekly } \\
\text { intake. }\end{array}$ & C57BL/6J mice & $\begin{array}{l}\text { 16S rDNA } \\
\text { sequencing. } \\
\text { Fecal microbiota } \\
\text { transplant. }\end{array}$ & $\begin{array}{l}\text { Early exposure to low dose of } \\
\text { cadmium results in } \\
\text { adiposities in adult male mice } \\
\text { as well as in reduced diversity } \\
\text { and altered composition of } \\
\text { gut microbiota. }\end{array}$ & $\begin{array}{l}\text { Early exposure to } \\
\text { cadmium resulted in } \\
\text { increased fat deposits in } \\
\text { male but not in female } \\
\text { mice. Low cadmium } \\
\text { concentrations increased } \\
\text { the expression of genes } \\
\text { related to } \\
\text { lipid metabolism. }\end{array}$ \\
\hline $\begin{array}{l}\text { Wu et al. } \\
\text { (2016) [43] }\end{array}$ & Metals (Lead) & $32 \mathrm{ppm}$ & $\begin{array}{c}\text { Relevant } \\
\text { concentration of } \\
\mathrm{Pb} \text { acetate in } \\
\text { drinking water. }\end{array}$ & $\begin{array}{l}\text { Non-agouti (a/a) } \\
\text { AVy mice } \\
\text { offspring }\end{array}$ & $\begin{array}{l}16 \mathrm{~S} \text { rRNA } \\
\text { gene sequencing. }\end{array}$ & $\begin{array}{l}\text { Perinatal Pb exposure was } \\
\text { significantly associated with } \\
\text { increased bodyweight in } \\
\text { adult males }(p<0.05) \text { but not } \\
\text { in females }(p=0.24) \text {. } \\
\text { Perinatal } \mathrm{Pb} \text { exposure altered } \\
\text { gut microbiota composition in } \\
\text { adult offspring, even after } \\
\text { stopping exposure at } 3 \text { weeks } \\
\text { (sex-independent). } \\
\text { Pseudomonas, Enterobacter, } \\
\text { and Desulfovibrio increased in } \\
\text { adult mice perinatally } \\
\text { exposed to } \mathrm{Pb}(p<0.05) \text {. }\end{array}$ & $\begin{array}{l}\text { Perinatal } \mathrm{Pb} \text { exposure was } \\
\text { associated with } \\
\text { bodyweight } \\
\text { (sex-dependent response) } \\
\text { and with microbiota } \\
\text { composition changes } \\
\text { (sex-independent). }\end{array}$ \\
\hline $\begin{array}{l}\text { Xia et al. } \\
\text { (2018) [44] }\end{array}$ & Metals (Lead) & 10 and $30 \mu \mathrm{g} / \mathrm{L}$ & $\begin{array}{l}\text { Exposure dose is } \\
\text { below the } \\
\text { maximum } \\
\text { allowable } \\
\text { concentration of } \\
\text { lead in water for } \\
\text { zebrafish }=0.07 \mathrm{mg} / \mathrm{L} \text {. }\end{array}$ & Zebrafish & $\begin{array}{l}16 \mathrm{~S} \text { rRNA gene } \\
\text { sequencing and GC/MS } \\
\text { metabolomics analysis. }\end{array}$ & $\begin{array}{c}\text { Exposure to } 30 \mu \mathrm{g} / \mathrm{L} \mathrm{Pb} \\
\text { resulted in decrased } \\
\alpha \text {-Proteobacteria } \\
\text { and increased Firmicutes. } \\
\text { GC/MS metabolomics } \\
\text { analysis showed that } 41 \\
\text { metabolites were altered in } \\
\text { the exposed group. } \\
\text { Changes were related to } \\
\text { glycolysis and lipid, } \\
\text { amino acid metabolism, } \\
\text { and nucleotide metabolism. }\end{array}$ & $\begin{array}{l}\mathrm{Pb} \text { exposure at } 10 \text { and } 30 \\
\mu \mathrm{g} / \mathrm{L} \text { during } 7 \text { days was } \\
\text { associated with changes in } \\
\text { microbiota and in glucose, } \\
\text { lipid, amino acid, } \\
\text { and nucleotide metabolism. }\end{array}$ \\
\hline
\end{tabular}


Table 2. Cont

\begin{tabular}{|c|c|c|c|c|c|c|c|}
\hline References & Compound & Dose Exposure & $\begin{array}{l}\text { Justification of } \\
\text { Exposure Dose }\end{array}$ & $\begin{array}{c}\text { Species Strain } \\
\text { Mode }\end{array}$ & Methods & Outcomes & Conclusions \\
\hline Lu et al. (2014) [45] & Metals (Arsenic) & $\begin{array}{c}10 \mathrm{ppm} \text { as } \\
\text { sodium arsenite }\end{array}$ & $\begin{array}{l}\text { The exposure dose } \\
\text { is above the } \\
\text { maximum } \\
\text { allowable } \\
\text { concentration of } \\
\text { arsenic in food. }\end{array}$ & C57BL/6 mice & $\begin{array}{l}\text { 16S rRNA gene } \\
\text { sequencing and } \\
\text { MS-based } \\
\text { metabolomics profiling. }\end{array}$ & $\begin{array}{l}\text { The most abundant gut } \\
\text { bacteria were } \\
\text { Firmicutes }(52.79 \%) \text { and } \\
\text { Bacteroidetes }(41.57 \%), \\
\text { followed by Tenericutes }(3 \%), \\
\text { Actinobacteria }(0.18 \%), \\
\text { Cyanobacteria }(0.023 \%), \\
\text { and Proteobacteria }(0.0042 \%)\end{array}$ & $\begin{array}{c}\text { Altered gut bacteria were } \\
\text { strongly linked to changes } \\
\text { in the } \\
\text { microbiota metabolites. } \\
\text { These changes increase } \\
\text { the risk of tissue } \\
\text { dysfunctions that might } \\
\text { lead to obesity, } \\
\text { insulin resistance, } \\
\text { and cardiovascular disease. }\end{array}$ \\
\hline $\begin{array}{l}\text { Catron et al. } \\
\text { (2019) [29] }\end{array}$ & $\begin{array}{c}\text { BPA, BPAF, BPB, } \\
\text { BPF, and BPS }\end{array}$ & $\begin{array}{c}\text { BPA }(0,0.2,0.6,1.7, \\
2.9,5.7,11.5,23.0, \text { or } \\
45.0 \mu \mathrm{M}), \text { BPAF }(0, \\
0.2,0.6,1.8,5.2,15.3 \\
\text { or } 45.0 \mu \mathrm{M}) \\
\text { BPB }(0,0.6,1.7,5.1, \\
15.0, \text { or } 44.0 \mu \mathrm{M}) \\
\text { BPF }(0,0.2,0.6,1.8 \\
5.2,15.3, \text { or } 45.0 \mu \mathrm{M}) \\
\text { or BPS }(0,0.2,0.6,1.8 \\
5.2,15.3, \text { or } 45.0 \mu \mathrm{M})\end{array}$ & $\begin{array}{l}\text { Dose based on } \\
\text { zebrafish toxicity } \\
\text { data available } \\
\text { through the iCSS } \\
\text { ToxCast dashboard } \\
\text { and previous } \\
\text { zebrafish studies. }\end{array}$ & Zebrafish & $\begin{array}{c}16 \mathrm{~S} \text { rRNA } \\
\text { gene sequencing. }\end{array}$ & $\begin{array}{c}\text { Exposure to all the tested } \\
\text { concentrations of BPS resulted } \\
\text { in non-detectable levels of the } \\
\text { Neisseriaceae family. } \\
\text { Increasing BPS } \\
\text { concentrations were } \\
\text { associated with increased } \\
\text { abundances of Cryomorphaceae. } \\
\text { Increasing BPA or BPF } \\
\text { concentrations were } \\
\text { associated with increased } \\
\text { abundances of Chromatiaceae } \\
\text { and decreased abundances } \\
\text { of Neisseriaceae. }\end{array}$ & $\begin{array}{l}\text { BPS, BPA, or BPF } \\
\text { exposure led to structural } \\
\text { microbiota disruption } \\
\text { during early development } \\
\text { at concentrations not } \\
\text { related to evident } \\
\text { developmental toxicity. } \\
\text { Results show that } \\
\text { microbiota is very useful } \\
\text { for characterization of } \\
\text { health effects associated } \\
\text { with exposure to } \\
\text { environmental chemicals. }\end{array}$ \\
\hline $\begin{array}{l}\text { Chen, et al. } \\
\text { (2018) [30] }\end{array}$ & BPA & 0,2 , and $20 \mu \mathrm{g} / \mathrm{L}$ & $\begin{array}{l}\text { Environmental } \\
\text { concentrations. }\end{array}$ & $\begin{array}{c}\text { Zefrafish } \\
\text { (Danio rerio) }\end{array}$ & $\begin{array}{l}\text { 16S rRNA } \\
\text { gene sequencing. }\end{array}$ & $\begin{array}{c}\mathrm{Nano}^{-\mathrm{TiO}_{2}} \text { and BPA } \\
\text { co-exposure led to altered } \\
\text { composition of guy } \\
\text { microbiota with increased } \\
\text { Proteobacteria and } \\
\text { Actinobacteria in males and } \\
\text { females. Hyphomicrobium was } \\
\text { the most abundant genus in } \\
\text { males and females. }\end{array}$ & $\begin{array}{l}\text { Co-exposure to nano-TiO } \\
2 \text { and BPA modifies gut } \\
\text { microbiome dynamics, } \\
\text { having toxicological } \\
\text { effects on host health. }\end{array}$ \\
\hline
\end{tabular}


Table 2. Cont

\begin{tabular}{|c|c|c|c|c|c|c|c|}
\hline References & Compound & Dose Exposure & $\begin{array}{l}\text { Justification of } \\
\text { Exposure Dose }\end{array}$ & $\begin{array}{l}\text { Species Strain } \\
\text { Mode }\end{array}$ & Methods & Outcomes & Conclusions \\
\hline $\begin{array}{l}\text { DeLuca et al. } \\
\text { (2018) [46] }\end{array}$ & BPA & $50 \mu \mathrm{g} / \mathrm{kg} \mathrm{bw}$ & $\begin{array}{l}\text { Lowest observed adverse } \\
\text { effect level. }\end{array}$ & C57BL/6 mice & $\begin{array}{l}\text { IMAC at Texas } \\
\text { A\&M University } \\
\text { and triple } \\
\text { quadrupole mass } \\
\text { spectrometer } \\
\text { coupled to LC. }\end{array}$ & $\begin{array}{l}\text { Exposure to BPA increased } \\
\text { mortality, disease activity, and } \\
\text { scores of colonic inflammation } \\
\text { colon after exposure to sodium } \\
\text { dextran sulfate. }\end{array}$ & $\begin{array}{l}\text { BPA exposure decreased } \\
\text { microbiota metabolites } \\
\text { derived from aromatic } \\
\text { amino acids and } \\
\text { associated with } \\
\text { colon inflammation } \\
\text { and inflammatory } \\
\text { bowel disease. }\end{array}$ \\
\hline $\begin{array}{l}\text { Javurek et al. } \\
\text { (2016) [31] }\end{array}$ & BPA & $50 \mathrm{mg} / \mathrm{kg} \mathrm{bw}$ & $\begin{array}{l}\text { Environmental } \\
\text { exposure. }\end{array}$ & California mice & $\begin{array}{c}16 \mathrm{~S} \text { rRNA } \\
\text { gene sequencing. }\end{array}$ & $\begin{array}{l}\text { BPA exposure increased growth } \\
\text { of pathogenic bacteria } \\
\text { (Bacteroides, Mollicutes, and } \\
\text { Prevotellaceae, among others) } \\
\text { associated with inflammatory } \\
\text { bowel disease, } \\
\text { metabolic disorders, } \\
\text { and colorectal cancer. However, } \\
\text { increased Bifidobacterium was } \\
\text { also found after BPA exposure. }\end{array}$ & $\begin{array}{l}\text { Gut microbiota disruption } \\
\text { secondary to BPA } \\
\text { exposure is associated } \\
\text { with systemic effects, such } \\
\text { as inflammatory } \\
\text { bowel disease, } \\
\text { metabolic disorders, } \\
\text { and colorectal cancer. }\end{array}$ \\
\hline $\begin{array}{l}\text { Koestel et al. } \\
\text { (2017) [47] }\end{array}$ & BPA & $\begin{array}{c}52.2 \pm 19.3 \mathrm{ng} / \text { food } \\
\text { can or } 36.2 \pm 18.6 \\
\text { ng/food can }\end{array}$ & $\begin{array}{l}\text { BPA levels identified } \\
\text { in cans of diet. } \\
\text { Serum dog } \\
\text { concentrations } 2.2 \mathrm{ng} / \mathrm{mL} \text {, } \\
\text { similar to that which } \\
\text { has been reported } \\
\text { in humans. }\end{array}$ & Dogs & $\begin{array}{c}16 \mathrm{~S} \text { rRNA } \\
\text { gene sequencing. }\end{array}$ & $\begin{array}{l}\text { Exposure to high concentrations } \\
\text { of BPA was associated with } \\
\text { increased bicarbonate levels in } \\
\text { plasma and with changes in } \\
\text { fecal microbiota (increased } \\
\text { Clostrididiaceae, Bacteroides spp., } \\
\text { Clostridiales, Ruminococcus spp., } \\
\text { Lachnospiraceae, Roseburia spp., } \\
\text { Clostridium hiranonis, and } \\
\text { Megamonas spp.). }\end{array}$ & $\begin{array}{l}\text { Exposure to high } \\
\text { concentrations of BPA } \\
\text { was associated with } \\
\text { decreased Bacteroides spp. } \\
\text { which is related to } \\
\text { reduction in bacterial } \\
\text { bisphenol degradation. } \\
\text { This increases active BPA } \\
\text { available for absorption in } \\
\text { the gut. }\end{array}$ \\
\hline $\begin{array}{l}\text { Lai et al. } \\
\text { (2016) [48] }\end{array}$ & BPA & $\begin{array}{l}\text { Unknown concentration } \\
\text { (BPA content in } \\
\text { contaminated diet) }\end{array}$ & n.a. & CD-1 mice & $\begin{array}{c}\text { LC-MS/MS, } \\
\text { 16S rRNA } \\
\text { gene sequencing, } \\
\text { and amplicon PCR. }\end{array}$ & $\begin{array}{l}\text { BPA and high-fat diet promoted } \\
\text { growth of Proteobacteria } \\
\text { (indicator of dysbiosis). } \\
\text { Increased Helicobacteraceae } \\
\text { proliferation and reduced } \\
\text { Firmicutes and Clostridia were } \\
\text { found in exposed mice. }\end{array}$ & $\begin{array}{l}\text { Exposure to BPA in the } \\
\text { diet led to structural } \\
\text { changes in gut microbiota } \\
\text { similar to those induced } \\
\text { by high-fat diet and } \\
\text { high-sucrose diet. }\end{array}$ \\
\hline
\end{tabular}


Table 2. Cont

\begin{tabular}{|c|c|c|c|c|c|c|c|}
\hline References & Compound & Dose Exposure & $\begin{array}{l}\text { Justification of } \\
\text { Exposure Dose }\end{array}$ & $\begin{array}{c}\text { Species Strain } \\
\text { Mode }\end{array}$ & Methods & Outcomes & Conclusions \\
\hline $\begin{array}{l}\text { Liu et al. } \\
\text { (2016) [32] }\end{array}$ & BPA & $2000 \mu \mathrm{g} / \mathrm{L}$ & $\begin{array}{l}\text { Dose used to } \\
\text { simulate environmental } \\
\text { exposure for a short } \\
\text { period of exposure. }\end{array}$ & Zebrafish & $\begin{array}{c}16 \mathrm{~S} \text { rRNA } \\
\text { gene sequencing } \\
\text { and amplicon } \\
\text { PCR reaction. }\end{array}$ & $\begin{array}{l}\text { BPA exposure significantly } \\
\text { modified gut microbiota } \\
\text { composition with increased } \\
\text { CKC4 phylum in male and } \\
\text { female zebrafish. }\end{array}$ & $\begin{array}{l}\text { BPA exposure altered gut } \\
\text { microbiota composition. } \\
\text { Gut dysbiosis may be } \\
\text { related to changes in lipid } \\
\text { metabolism of the host } \\
\text { (increased triglycerides in } \\
\text { the muscle). }\end{array}$ \\
\hline $\begin{array}{l}\text { Malaise et al. } \\
\text { (2017) [5] }\end{array}$ & BPA & $50 \mu \mathrm{g} / \mathrm{kg}$ bw & $\begin{array}{l}\text { Exposure dose is } 100 \\
\text { times below the } \\
\text { current NOAEL in } \\
\text { mice. NOAEL= } \\
5 \mathrm{mg} / \mathrm{kg} \text { BW/day }\end{array}$ & Mice & $\begin{array}{l}\text { 16S rRNA gene } \\
\text { sequencing and } \\
\text { Real time PCR. }\end{array}$ & $\begin{array}{l}\text { Perinatal oral exposure to } 50 \\
\mu \mathrm{g} / \mathrm{kg} \text { BPA led to gut and } \\
\text { systemic immune changes in } \\
\text { post-natal day } 45 . \\
\text { These changes were linked to } \\
\text { altered glucose sensitivity and } \\
\text { secretion of IgA in feces and } \\
\text { decreased fecal Bifidobacteria } \\
\text { compared to mice in the } \\
\text { control group. These effects } \\
\text { appear before the infiltration } \\
\text { with proinflammatory M1 } \\
\text { macrophages in gonadal } \\
\text { white adipose tissue that } \\
\text { appears with aging, along } \\
\text { with decreased insulin } \\
\text { sensitivity (T1D) and } \\
\text { weight gain. }\end{array}$ & $\begin{array}{l}\text { The results explain the } \\
\text { sequence of changes } \\
\text { related to perinatal } \\
\text { exposure to BPA which } \\
\text { could also explain the } \\
\text { development of metabolic } \\
\text { diseases in adulthood } \\
\text { (decreased insulin } \\
\text { sensitivity and increased } \\
\text { weight gain). }\end{array}$ \\
\hline $\begin{array}{l}\text { Reddivari et al. } \\
\text { (2017) [49] }\end{array}$ & BPA & $200 \mu \mathrm{g} / \mathrm{kg}$ bw & $\begin{array}{c}\text { To ensure } \\
\text { gestational and } \\
\text { lactational exposure } \\
\text { of pups, } \\
\text { approximately } 1 / 25 \\
\text { of the NOAEL dose. }\end{array}$ & Rabbits & $\begin{array}{c}16 \mathrm{~S} \text { rRNA } \\
\text { gene sequencing. }\end{array}$ & $\begin{array}{l}\text { BPA exposure induced } \\
\text { significant decrease in } \\
\text { Oscillospira and } \\
\text { Ruminococcaceae and therefore } \\
\text { in short-chain fatty acid } \\
\text { production. BPA exposure } \\
\text { also reduced fecal levels of } \\
\text { short-chain fatty acid, } \\
\text { and increased systemic } \\
\text { lipopolysaccharide and gut } \\
\text { permeability. }\end{array}$ & $\begin{array}{c}\text { Perinatal exposure to BPA } \\
\text { modified gut microbiota } \\
\text { composition and } \\
\text { decreased beneficial } \\
\text { bacterial metabolites such } \\
\text { as short-chain fatty acids. } \\
\text { BPA exposure also } \\
\text { increased chronic } \\
\text { inflammation in colon } \\
\text { and liver, and systemic } \\
\text { lipopolysaccharides. }\end{array}$ \\
\hline
\end{tabular}


Table 2. Cont

\begin{tabular}{|c|c|c|c|c|c|c|c|}
\hline References & Compound & Dose Exposure & $\begin{array}{l}\text { Justification of } \\
\text { Exposure Dose }\end{array}$ & $\begin{array}{c}\text { Species Strain } \\
\text { Mode }\end{array}$ & Methods & Outcomes & Conclusions \\
\hline $\begin{array}{l}\text { Xu et al. } \\
\text { (2019) [33] }\end{array}$ & BPA & 30 or $300 \mu \mathrm{g} / \mathrm{kg}$ bw & $\begin{array}{c}\text { Based on } \\
\text { human exposure } \\
(30 \mu \mathrm{g} / \mathrm{kg}) \\
\text { and median } \\
\text { human blood } \\
(300 \mu \mathrm{g} / \mathrm{kg}) \text { levels }\end{array}$ & Mice & $\begin{array}{c}\text { 16S rRNA } \\
\text { gene sequencing } \\
\text { and amplicon } \\
\text { PCR reaction. }\end{array}$ & $\begin{array}{c}\text { BPA exposure-induced } \\
\text { changes in gut microbiome } \\
\text { composition are a potential } \\
\text { mechanism of } \\
\text { immunomodulation and T1D } \\
\text { development. BPA at } 30 \text { or } \\
300 \mu \mathrm{g} / \mathrm{kg} \text { increased } \\
\text { Bacteroidetes, and } 300 \mu \mathrm{g} / \mathrm{kg} \\
\text { increased Cyanobacteria } \\
\text { and TM7. The } 30 \mu \mathrm{g} / \mathrm{kg} \text { dose } \\
\text { decreased Proteobacteria, and } \\
300 \mu \mathrm{g} / \mathrm{kg} \text { decreased } \\
\text { Firmicutes and Tenericutes. } \\
\text { Females showed an increase } \\
\text { in pro-inflammatory factors, } \\
\text { while males showed an } \\
\text { increase in anti-inflammatory } \\
\text { immune factors. }\end{array}$ & $\begin{array}{l}\text { Altered gut microbiota } \\
\text { and inflammation risk } \\
\text { factors for T1D } \\
\text { development associated } \\
\text { with BPA exposure were } \\
\text { sex-dependent. }\end{array}$ \\
\hline Xu et al. (2019) [6] & BPA & 30 or $300 \mu \mathrm{g} / \mathrm{kg}$ bw & $\begin{array}{c}\text { To accelerate } \\
\text { Diabetes type I } \\
\text { development ( } 30 \\
\mu \mathrm{g} / \mathrm{kg} \mathrm{bw}) \text { and } \\
\text { alter the immunity } \\
(300 \mu \mathrm{g} / \mathrm{kg} \mathrm{bw}) .\end{array}$ & Mice & $\begin{array}{l}\text { 16S rRNA } \\
\text { gene sequencing } \\
\text { and amplicon } \\
\text { PCR reaction }\end{array}$ & $\begin{array}{l}\text { Adult females showed a } \\
\text { higher risk of T1D and } \\
\text { increased immune responses. } \\
\text { However, female offspring } \\
\text { showed lower risk of T1D and } \\
\text { a shift towards } \\
\text { anti-inflammation. } \\
\text { In contrast, BPA exposure } \\
\text { had little impact on DT1 and } \\
\text { immunity in male offspring. }\end{array}$ & $\begin{array}{l}\text { BPA effects on the } \\
\text { development of T1D were } \\
\text { related to host age and } \\
\text { gender. Changes in gut } \\
\text { microbiota and } \\
\text { inflammation are } \\
\text { responsible for T1D in } \\
\text { juvenile exposure. } \\
\text { Decreased inflammation is } \\
\text { responsible for attenuated } \\
\text { T1D in males and female } \\
\text { offspring exposed during } \\
\text { the perinatal period. }\end{array}$ \\
\hline
\end{tabular}


Table 2. Cont

\begin{tabular}{|c|c|c|c|c|c|c|c|}
\hline References & Compound & Dose Exposure & $\begin{array}{l}\text { Justification of } \\
\text { Exposure Dose }\end{array}$ & $\begin{array}{c}\text { Species Strain } \\
\text { Mode }\end{array}$ & Methods & Outcomes & Conclusions \\
\hline $\begin{array}{l}\text { Chen, et al. } \\
\text { (2018) [50] }\end{array}$ & $\begin{array}{l}\text { PCB126 and } \\
\text { PCB153 }\end{array}$ & $1.0 \mu \mathrm{g} / \mathrm{L}$ & $\begin{array}{l}\text { Concentration below the } \\
\text { limit established } \\
\text { by EPA. }\end{array}$ & Zefrafish & $\begin{array}{l}16 \mathrm{~S} \text { rRNA } \\
\text { gene sequencing. }\end{array}$ & $\begin{array}{l}\text { PCB126 exposure led to } \\
\text { altered microbiota and } \\
\text { deterioration of the intestinal } \\
\text { and hepatic functions. } \\
\text { PCB126 was associated with } \\
\text { oxidative stress and with a } \\
\text { sexual dysmorphic effect. } \\
\text { Exposure to PCB126 was } \\
\text { significantly associated with } \\
\text { oxidative stress, and exposure } \\
\text { to PCB153 was associated } \\
\text { with lower body weight, } \\
\text { higher hepatosomatic index } \\
\text { in female zebrafish, but lower } \\
\text { index value in exposed } \\
\text { males PCB153. }\end{array}$ & $\begin{array}{c}\text { Exposure to PCB126 } \\
\text { showed a significant } \\
\text { correlation between } \\
\text { dysbiosis and fish health. }\end{array}$ \\
\hline $\begin{array}{l}\text { Cheng et al. } \\
\text { (2018) [51] }\end{array}$ & PCBs & 6 or $30 \mathrm{mg} / \mathrm{kg}$ & $\begin{array}{c}\text { To study } \\
\text { dose-dependent effect } \\
\text { of xenobiotics on the } \\
\text { expression of } \\
\text { hepatic drug } \\
\text { metabolizing enzymes. }\end{array}$ & C57BL/6 mice & $\begin{array}{c}\text { 16S rRNA } \\
\text { sequencing, } \\
\text { quantitative PCR, } \\
\text { and UPLC-MS/MS }\end{array}$ & $\begin{array}{l}\text { Exposure to } 6 \mathrm{mg} / \mathrm{kg} \text { PCBs } \\
\text { greatly increased the bacteria } \\
\text { related to the metabolism of } \\
\text { bile acids. This was } \\
\text { associated with increased bile } \\
\text { acids in serum } \\
\text { and small intestine content in a } \\
\text { microbiota-dependent fashion. } \\
\text { However, at } 30 \mathrm{mg} / \mathrm{kg} \text { PCBs, } \\
\text { bile acid levels remained } \\
\text { stable and were linked with } \\
\text { increased hepatic flow } \\
\text { transporters and ileal Fgf15. }\end{array}$ & $\begin{array}{l}\text { Changes in microbiota } \\
\text { promoted increase in } \\
\text { taurine mediated by PCBs } \\
\text { in the muricholic acids } \alpha \\
\text { and } \beta \text { conjugated with } \\
\text { taurine in liver, large and } \\
\text { small intestine. }\end{array}$ \\
\hline $\begin{array}{c}\text { Chi et al. (2019) } \\
\text { [52] }\end{array}$ & PCB126 & $50 \mu \mathrm{g} / \mathrm{kg}$ bw & $\begin{array}{c}\text { Dose environmentally } \\
\text { relevant to } \\
\text { concentrations } \\
\text { historically reported } \\
\text { in lake trout from the } \\
\text { Great Lakes. }\end{array}$ & C57BL/6 mice & $\begin{array}{l}\text { 16S rRNA gene } \\
\text { sequencing and } \\
\text { qRT-PCR }\end{array}$ & $\begin{array}{l}\text { Exposure to PCB126 induced } \\
\text { gut dysbiosis (increased } \\
\text { Firmicutes and Bacteroidetes } \\
\text { and decreased Erysipelotrichia) } \\
\text { as well as dyslipidemia and } \\
\text { nonalcoholic fatty } \\
\text { liver disease. }\end{array}$ & $\begin{array}{l}\text { Exposure to low doses of } \\
\text { PCB-126 in mice caused } \\
\text { intestinal microbiota } \\
\text { dysbiosis and multiple } \\
\text { disorders in serum } \\
\text { and liver. }\end{array}$ \\
\hline
\end{tabular}


Table 2. Cont

\begin{tabular}{|c|c|c|c|c|c|c|c|}
\hline References & Compound & Dose Exposure & $\begin{array}{l}\text { Justification of } \\
\text { Exposure Dose }\end{array}$ & $\begin{array}{c}\text { Species Strain } \\
\text { Mode }\end{array}$ & Methods & Outcomes & Conclusions \\
\hline $\begin{array}{l}\text { Choi et al. } \\
\text { (2013) [53] }\end{array}$ & $\begin{array}{l}\text { PCB153, PCB138, } \\
\text { and PCB180 }\end{array}$ & $150 \mu \mathrm{mol} / \mathrm{kg}$ & $\begin{array}{c}\text { PCB content in } \\
\text { contaminated food. }\end{array}$ & C57BL/6 mice & $\begin{array}{c}\text { 16S rRNA gene } \\
\text { sequencing } \\
\text { and PCR. }\end{array}$ & $\begin{array}{c}\text { Exposure to PCBs in } \\
\text { sedentary mice resulted in } \\
\text { decreased abundance } \\
\text { of Proteobacteria. } \\
\text { Exercised mice showed a gut } \\
\text { microbiome structure } \\
\text { significantly different from } \\
\text { sedentary mice. } \\
\text { Exercise lessened } \\
\text { PCB-induced changes in } \\
\text { gut microbiome. }\end{array}$ & $\begin{array}{c}\text { Exposure to PCBs } \\
\text { promotes changes in } \\
\text { gut microbiome, } \\
\text { which can determine } \\
\text { systemic toxicity. } \\
\text { Physical exercise lessens } \\
\text { changes in } \\
\text { gut microbiome. }\end{array}$ \\
\hline $\begin{array}{l}\text { Kohl et al. } \\
\text { (2015) [54] }\end{array}$ & PCB126 & $7.3 \mathrm{ng} / \mathrm{g}$ & $\begin{array}{l}\text { The exposure } \\
\text { concentration is } \\
\text { below the } \\
\text { maximum } \\
\text { allowable } \\
\text { concentration of } \\
\text { PCBs in food. }\end{array}$ & $\begin{array}{l}\text { Northern leopard } \\
\text { frogs (L. pipiens) }\end{array}$ & $\begin{array}{c}16 \mathrm{~S} \text { rRNA } \\
\text { gene sequencing }\end{array}$ & $\begin{array}{c}\text { Tadpoles exposed to PCB126 } \\
\text { maintained increased } \\
\text { Fusobacteria }(\mathrm{t}=2.95 ; \mathrm{df}=14 ; \\
p=0.01) \text {. Fusobacteria was a } \\
\text { very small portion of the } \\
\text { tadpole (average of control } \\
\text { and treated with PCB: } 0.008 \%) \\
\text { and control frog }(0.3 \pm 0.1 \%) \\
\text { gut communities. Frogs } \\
\text { exposed to PCB126 during } \\
\text { larval stage had a relative } \\
\text { Fusobacterial abundance of } \\
3.5 \pm 1.4 \% \text {. }\end{array}$ & $\begin{array}{l}\text { Exposure to PCB126 } \\
\text { results in changes in gut } \\
\text { microbiota communities } \\
\text { which might affect health } \\
\text { and fitness of the host. }\end{array}$ \\
\hline $\begin{array}{l}\text { Petriello et al. } \\
\text { (2018) [55] }\end{array}$ & PCB126 & $1 \mu \mathrm{mol} / \mathrm{kg}$ & $\begin{array}{l}\text { This dose } \\
\text { produces plasma } \\
\text { PCB } 126 \text { levels that } \\
\text { mimic human } \\
\text { exposures of } \\
\text { dioxin-like } \\
\text { pollutants. }\end{array}$ & $L d l r-/-$ mice & $\begin{array}{l}\text { 16S rRNA gene } \\
\text { sequencing and } \\
\text { regression } \\
\text { modeling. }\end{array}$ & $\begin{array}{l}\text { PCB126 reduced } \alpha \text { diversity } \\
\text { ( } p=0.001) \text { in the colon and } \\
\text { increased the Firmicutes to } \\
\text { Bacteroidetes ratio ( } p=0.044) \text {. } \\
\text { Quantifiable amounts of } \\
\text { PCB126 in the colon, } \\
\text { upregulation of Cyp1a1 } \\
\text { gene expression, } \\
\text { and increased indicators of } \\
\text { gut inflammation were found } \\
\text { in exposed mice. }\end{array}$ & $\begin{array}{l}\text { PCB126 exposure altered } \\
\text { gut microbiota and } \\
\text { metabolism and resulted } \\
\text { in gut and } \\
\text { systemic inflammation. }\end{array}$ \\
\hline
\end{tabular}


Table 2. Cont.

\begin{tabular}{|c|c|c|c|c|c|c|c|}
\hline References & Compound & Dose Exposure & $\begin{array}{l}\text { Justification of } \\
\text { Exposure Dose }\end{array}$ & $\begin{array}{l}\text { pecies Strain } \\
\text { Mode }\end{array}$ & Methods & Outcomes & Conclusions \\
\hline $\begin{array}{l}\text { Rude et al. } \\
\text { (2019) [56] }\end{array}$ & PCBs & $\begin{array}{l}0.1,1, \text { or } 6 \\
\mathrm{mg} / \mathrm{kg} / \text { day }\end{array}$ & $\begin{array}{l}\text { FDA mandates } \\
\text { tolerances of } \\
0.2-3.0 \mathrm{ppm} \\
(200-3000 \mathrm{ng} / \mathrm{g}) \text { for } \\
\text { all foods. }\end{array}$ & Mice & $\begin{array}{l}\text { qPCR and } 16 \mathrm{~S} \\
\text { rRNA gene } \\
\text { sequencing. }\end{array}$ & $\begin{array}{l}\text { PCB exposure resulted in } \\
\text { epithelial permeability defects } \\
\text { in the ileum and colon of } \\
\text { juvenile mutated mice. PCB } \\
\text { exposure also promoted } \\
\text { intestinal inflammation } \\
\text { dysbiosis in gut microbiota in } \\
\text { juvenile mutated mice } \\
\text { exposed to } 1 \mathrm{mg} / \mathrm{kg} / \mathrm{d} \text { PCBs } \\
\text { versus controls. }\end{array}$ & $\begin{array}{l}\text { The results showed the } \\
\text { interactions between } \\
\text { PCBs and genetic } \\
\text { susceptibility factors to } \\
\text { impact individual risk. }\end{array}$ \\
\hline $\begin{array}{l}\text { Horiuchi et al. } \\
\text { (2017) [57] }\end{array}$ & $\begin{array}{l}\text { Phytoestrogen } \\
\text { (S-equol) }\end{array}$ & $20 \mathrm{mg} / \mathrm{kg}$, 2 times $/ \mathrm{d}$ & $\begin{array}{c}\text { Doses based on } \\
\text { previous studies of } \\
\text { the possible } \\
\text { benefits of S-equol } \\
\text { on diabetes. }\end{array}$ & Mice & $\begin{array}{l}\text { Immunochemistry. } \\
\text { Insulin secretion } \\
\text { assay. qRT-PCR. }\end{array}$ & $\begin{array}{l}\text { Administration of S-equol } \\
\text { resulted in reduction of the } \\
\text { induction of blood } \\
\text { glucose concentrations } \\
\text { ( } p<0.01 \text { at } 15 \mathrm{~min}, p<0.01 \text { at } \\
30 \mathrm{~min}, p<0.05 \text { at } 60 \mathrm{~min}, \\
\text { and } p<0.01 \text { at } 120 \mathrm{~min} \text { ) }\end{array}$ & $\begin{array}{l}\text { Gut microbiota-produced } \\
\text { S-equol induced } \beta \text {-cell } \\
\text { growth in vivo and } \\
\text { insulin secretion ex vivo. } \\
\text { Administration of } \\
\text { S-equol decreased } \\
\text { Streptozotocin-induced } \\
\text { hyperglycemia by } \\
\text { promoting } \beta \text {-cell function. }\end{array}$ \\
\hline $\begin{array}{l}\text { Huang et al. } \\
\text { (2018) [58] }\end{array}$ & $\begin{array}{l}\text { Phytoestrogens } \\
\text { (Genistein) }\end{array}$ & $20 \mathrm{mg} / \mathrm{kg}$ bw & $\begin{array}{l}\text { Dose } \\
\text { physiologically } \\
\text { relevant to obtain } \\
\text { an accurate } \\
\text { interspecies extrapolation. }\end{array}$ & Mice & $\begin{array}{l}\text { 16S rRNA gene } \\
\text { sequencing and } \\
\text { qRT-PCR. }\end{array}$ & $\begin{array}{c}\text { Perinatal genistein exposure } \\
\text { caused increased incidence of } \\
\text { DT1 in female offspring. Fecal } \\
\text { microbiota from female } \\
\text { offspring at postnatal day } 90 \\
\text { showed increased } \\
\text { Enterobacteriales (suggesting a } \\
\text { proinflammatory response). } \\
\text { In contrast, } \\
\text { perinatal genistein } \\
\text { administration caused a shift } \\
\text { in microbiota towards } \\
\text { anti-inflammation in males at } \\
\text { postnatal day } 90 .\end{array}$ & $\begin{array}{c}\text { Perinatal administration } \\
\text { of genistein resulted in } \\
\text { strongly sex-dependent } \\
\text { changes in microbiota. } \\
\text { T1D exacerbation in } \\
\text { non-diabetic females was } \\
\text { related to } \\
\text { immunomodulatory } \\
\text { mechanisms associated } \\
\text { with an altered } \\
\text { gut microbiota. }\end{array}$ \\
\hline
\end{tabular}


Table 2. Cont

\begin{tabular}{|c|c|c|c|c|c|c|c|}
\hline References & Compound & Dose Exposure & $\begin{array}{l}\text { Justification of } \\
\text { Exposure Dose }\end{array}$ & $\begin{array}{c}\text { Species Strain } \\
\text { Mode }\end{array}$ & Methods & Outcomes & Conclusions \\
\hline $\begin{array}{l}\text { López et al. } \\
\text { (2018) [59] }\end{array}$ & $\begin{array}{l}\text { Phytoestrogens } \\
\text { (Genistein) }\end{array}$ & $3 \mathrm{mg} / \mathrm{kg}$ bw/day & $\begin{array}{l}\text { Equivalent dose of } \\
1.5 \mathrm{~g} \text { of genistein } \\
\text { per day for a } 65 \mathrm{~kg} \\
\text { adult person, } \\
\text { approximately. }\end{array}$ & C57BL/6 mice & $\begin{array}{l}16 \mathrm{~S} \text { rRNA } \\
\text { gene sequencing } \\
\text { and qRT-PCR. }\end{array}$ & $\begin{array}{l}\text { Mice fed with a high-fat diet } \\
\text { with genistein exhibited } \\
\text { changes in the gut microbiota } \\
\text { linked to lower circulating } \\
\text { levels of lipopolysaccharides, } \\
\text { improved glucose metabolism, } \\
\text { and reduced expression of } \\
\text { pro-inflammatory cytokines } \\
\text { in the liver compared to mice } \\
\text { in the high-fat diet } \\
\text { alone group. }\end{array}$ & $\begin{array}{c}\text { Genistein exposure through } \\
\text { diet can modulate gut } \\
\text { microbiota, } \\
\text { decreasing metabolic } \\
\text { endotoxemia and } \\
\text { neuroinflammatory } \\
\text { response despite } \\
\text { consumption of a } \\
\text { high-fat diet. }\end{array}$ \\
\hline $\begin{array}{l}\text { Marshall et al. } \\
\text { (2019) [60] }\end{array}$ & $\begin{array}{l}\text { Phytoestrogens } \\
\text { (Genistein) }\end{array}$ & $250 \mathrm{mg} / \mathrm{kg}$ & $\begin{array}{l}\text { The dose is above } \\
\text { the maximum allowabl } \\
\text { concentration of } \\
\text { genistein in food. } \\
\text { EFSA LOAEL of } \\
35 \mathrm{mg} / \mathrm{kg} \text { bw/day } \\
\text { for males and } 44 \\
\mathrm{mg} / \mathrm{kg} \text { bw/day } \\
\text { for females }\end{array}$ & California mice & $\begin{array}{c}\text { GC/MS, } 16 \mathrm{~S} \text { rRNA } \\
\text { sequencing Social } \\
\text { behavior testing } \\
\text { using the } \\
\text { three-chamber test }\end{array}$ & $\begin{array}{l}\text { When male offspring from } \\
\text { genistein-supplemented } \\
\text { dams were compared with } \\
\text { genistein-free offspring, } \\
\text { audible calls above } 20 \mathrm{kHz} \\
\text { correlated with daidzein, } \\
\alpha \text {-tocopherol, Flexispira spp., } \\
\text { and Odoribacter spp. Results } \\
\text { suggest that early genistein } \\
\text { exposure can induce a } \\
\text { disruption in the } \\
\text { offspring's normal } \\
\text { socio-communicative behaviors. }\end{array}$ & $\begin{array}{l}\text { Perinatal exposure to } \\
\text { genistein may detrimentally } \\
\text { affect the offspring } \\
\text { "microbiome-gut-brain axis" } \\
\end{array}$ \\
\hline $\begin{array}{l}\text { Piccolo et al. } \\
\text { (2017) [61] }\end{array}$ & Phytoestrogens & $\begin{array}{c}\text { Phytoestrogens } \\
\text { naturally present } \\
\text { in diet (pigs fed } \\
\text { with soy-based } \\
\text { infant formula) }\end{array}$ & Food exposure levels. & $\begin{array}{l}\text { White Dutch } \\
\text { Landrace pigs }\end{array}$ & $\begin{array}{l}16 \mathrm{~S} \text { rRNA } \\
\text { gene sequencing } \\
\text { and LC-MS. }\end{array}$ & $\begin{array}{l}\text { Sow-fed piglets exhibited } \\
\text { higher } \alpha \text {-diversity in the } \\
\text { duodenum than formula-fed } \\
\text { piglets }(p<0.05) \text {. } \\
\text { No differences were found in } \\
\text { the ileum. Firmicutes was the } \\
\text { most abundant phylum in the } \\
\text { duodenum in all tested diets, } \\
\text { followed by Proteobacteria in } \\
\text { the sow-and milk-fed piglets } \\
\text { and Cyanobacteria in } \\
\text { soy-fed piglets. }\end{array}$ & $\begin{array}{l}\text { Neonatal diet can impact } \\
\text { small intestine microbiome } \\
\text { in pigs, resulting in } \\
\text { disturbances in the } \\
\text { metabolism and } \\
\text { development of intestinal } \\
\text { tissue in the } \\
\text { postnatal period. }\end{array}$ \\
\hline
\end{tabular}


Table 2. Cont

\begin{tabular}{|c|c|c|c|c|c|c|c|}
\hline References & Compound & Dose Exposure & $\begin{array}{l}\text { Justification of } \\
\text { Exposure Dose }\end{array}$ & $\begin{array}{l}\text { Species Strain } \\
\text { Mode }\end{array}$ & Methods & Outcomes & Conclusions \\
\hline $\begin{array}{l}\text { Williams et al. } \\
\text { (2019) [62] }\end{array}$ & Phytoestrogens & $\begin{array}{l}\text { Phytoestrogens } \\
\text { naturally present } \\
\text { in diet }\end{array}$ & Food exposure levels. & $\begin{array}{l}\text { Southern white } \\
\text { rhinoceros } \\
\text { (Ceratotherium } \\
\text { simum simum) }\end{array}$ & $\begin{array}{l}\text { 16S rRNA } \\
\text { amplicon sequencing } \\
\text { and MS. }\end{array}$ & $\begin{array}{l}\text { Composition and structure of } \\
\text { fecal microbiota significantly } \\
\text { giffers by rhino species as } \\
\text { well as at the phylum, family, } \\
\text { and OUT levels. }\end{array}$ & $\begin{array}{c}\text { Results suggest } \\
\text { differences in receptor } \\
\text { sensitivity to } \\
\text { phytoestrogens related to } \\
\text { the species and } \\
\text { metabolism of dietary } \\
\text { phytoestrogens by gut } \\
\text { microbiota might have an } \\
\text { impact on fertility of } \\
\text { captive female rhinos. }\end{array}$ \\
\hline $\begin{array}{l}\text { Yeruva et al., } \\
\text { (2016) [63] }\end{array}$ & Phytoestrogens & $\begin{array}{l}\text { Phytoestrogens } \\
\text { naturally present in } \\
\text { diet (pigs were fed } \\
\text { soy or } \\
\text { milk formula). }\end{array}$ & Food exposure levels. & $\begin{array}{l}\text { White Dutch, } \\
\text { Landrace Duroc pigs }\end{array}$ & $\begin{array}{l}\text { 16S rRNA } \\
\text { amplicon } \\
\text { sequencing, } \\
\text { qRT-PCR, } \\
\text { ELISA and } \\
\text { UHPLC-HRAM. }\end{array}$ & $\begin{array}{c}\text { In soy-fed piglets, } \\
\text { increased Lactobacillaceae spp. } \\
\text { and Clostria spp. } \\
\text { but decreased Enterobacteriaceae } \\
\text { were observed. }\end{array}$ & $\begin{array}{l}\text { Neonatal diet promotes } \\
\text { disturbances in } \\
\text { microbiome of the small } \\
\text { intestine in pigs, } \\
\text { spp. } \\
\text { particularly in the } \\
\text { duodenum. }\end{array}$ \\
\hline $\begin{array}{l}\text { Zhou et al. } \\
\text { (2018) [64] }\end{array}$ & $\begin{array}{l}\text { Phytoestrogens } \\
\text { (Genistein) }\end{array}$ & 0.25 and $0.6 \mathrm{~g} / \mathrm{kg}$ & $\begin{array}{c}\text { To analyze the } \\
\text { effects of low and } \\
\text { high exposure doses. }\end{array}$ & C57BL/6 mice & $\begin{array}{l} \\
\text { Oral glucose } \\
\text { tolerance tests, } \\
\text { ELISA kit, } \\
\text { and 16S rRNA } \\
\text { amplicon sequencing. }\end{array}$ & $\begin{array}{l}\text { Perinatal maternal } \\
\text { consumption of a high-fat } \\
\text { diet with genistein resulted in } \\
\text { increased birth weight, } \\
\text { improved glucose tolerance } \\
\text { and decreased fasting insulin, } \\
\text { as well as lower levels of } \\
\text { triacylglycerol and total } \\
\text { cholesterol in serum } \\
\text { in the offspring. }\end{array}$ & $\begin{array}{l}\text { The intake of genistein } \\
\text { during pregnancy } \\
\text { improves the metabolism } \\
\text { of the offspring, } \\
\text { preventing the } \\
\text { transgenerational effects } \\
\text { of maternal high-fat diet } \\
\text { on diabetes. }\end{array}$ \\
\hline $\begin{array}{l}\text { Obadia et al. } \\
\text { (2018) [65] }\end{array}$ & $\begin{array}{l}\text { Methylparaben } \\
\text { (MPB) }\end{array}$ & $0.0,0.1,0.2$, and $0.3 \%$ & $\begin{array}{l}\text { High levels of MPB } \\
(\sim 0.5 \%) \text { can } \\
\text { affect the } \\
\text { microbiota diversity; } \\
\text { the exposure dose } \\
\text { was selected to test } \\
\text { lower levels. }\end{array}$ & $\begin{array}{l}\text { Drosophila } \\
\text { melanogaster }\end{array}$ & - & $\begin{array}{c}\text { Concentrations }>0.1 \% \text { MPB } \\
\text { disrupt the growth of some } \\
\text { species of yeast } \\
\text { and Acetobacter, but even at } \\
0.3 \% \text { Lactobacilli growth was } \\
\text { less affected. }\end{array}$ & $\begin{array}{l}\text { Exposure to MPB } \\
\text { probably alters the } \\
\text { composition and amount } \\
\text { of gut bacteria and yeasts } \\
\text { in laboratory fly. }\end{array}$ \\
\hline
\end{tabular}


Table 2. Cont

\begin{tabular}{|c|c|c|c|c|c|c|c|}
\hline References & Compound & Dose Exposure & $\begin{array}{l}\text { Justification of } \\
\text { Exposure Dose }\end{array}$ & $\begin{array}{c}\text { Species Strain } \\
\text { Mode }\end{array}$ & Methods & Outcomes & Conclusions \\
\hline $\begin{array}{l}\text { Hu et al. } \\
\text { (2016) [66] }\end{array}$ & $\begin{array}{cc}\text { Diethyl phthalate (DEP), } & 0 . \\
\text { methylparaben (MPB), } & 0 . \\
\text { triclosan (TCS) and } & \text { ar } \\
\text { their mixture (MIX) } & \end{array}$ & $\begin{array}{l}0.050 \mathrm{mg} \mathrm{TCS} / \mathrm{kg} \mathrm{bw} \text {, } \\
0.1050 \mathrm{mg} \mathrm{MPB} / \mathrm{kg} \mathrm{bw} \\
\text { and } 0.1735 \mathrm{mg} \mathrm{DEP} / \mathrm{kg} \mathrm{b}\end{array}$ & bw NOAEL. & Sprague-Dawley rats & $\begin{array}{l}16 \mathrm{~S} \text { rRNA } \\
\text { gene sequencing } \\
\text { and PCR. }\end{array}$ & $\begin{array}{l}\text { Exposure to these chemicals } \\
\text { produced an increase in } \\
\text { Bacteroidetes (Prevotella) and } \\
\text { decreased Firmicutes (Bacilli) } \\
\text { in all the exposed rats. } \\
\text { Increased Elusimicrobia was } \\
\text { found in DEP and MPB } \\
\text { exposed rats, } \\
\text { Betaproteobacteria in MPB } \\
\text { and MIX exposed rats, } \\
\text { and Deltaproteobacteria in the } \\
\text { TCS group. In adulthood, } \\
\text { these differences decreased } \\
\text { between cases and controls } \\
\text { despite continued exposure, } \\
\text { suggesting that contaminant } \\
\text { exposure have a greater } \\
\text { impact on gut microbiome of } \\
\text { adolescent rats. }\end{array}$ & $\begin{array}{l}\text { Exposure at doses similar to } \\
\text { environmental human exposure } \\
\text { can disturb the gut microbiota } \\
\text { in adolescent rats. } \\
\text { This disturbance mainly affects } \\
\text { the health of the youngest. }\end{array}$ \\
\hline $\begin{array}{l}\text { Fan et al. } \\
\text { (2020) [67] }\end{array}$ & Di (2-ethylhexyl)-phthalate & $\begin{array}{c}0.2,2, \\
\text { end } 20 \mathrm{mg} / \mathrm{kg} / \text { day }\end{array}$ & $\begin{array}{l}\text { Based on the } \\
\text { EPA reference } \\
\text { dose and } \\
\text { revious studies. }\end{array}$ & Mice & $\begin{array}{l}\text { LC-HRMS, } \\
\text { 16S rRNA } \\
\text { gene sequencing, } \\
\text { and qPCR. }\end{array}$ & $\begin{array}{c}\text { Prenatal exposure to low } \\
\text { doses of di (2-ethylhexyl) } \\
\text { phthalate }(0.2 \mathrm{mg} / \mathrm{kg} / \mathrm{day}) \\
\text { resulted in metabolic } \\
\text { syndrome and gut dysbiosis. } \\
\text { Thiamine liver metabolism } \\
\text { was disrupted in the offspring, } \\
\text { which caused disturbances in } \\
\text { glucose metabolism. }\end{array}$ & $\begin{array}{l}\text { Exposure to low doses of di } \\
\text { (2-ethylhexyl) phthalate during } \\
\text { the early stages of life might } \\
\text { increase the risk of obesity and } \\
\text { metabolic syndrome. }\end{array}$ \\
\hline $\begin{array}{l}\text { Lei et al. } \\
\text { (2019) [37] }\end{array}$ & Di (2-ethylhexyl)-phthalate & $e^{\begin{array}{c}1 \text { or } 10 \mathrm{mg} / \mathrm{kg} \\
\text { bw/day }\end{array}}$ & $\begin{array}{l}\text { The } \\
\text { concentration } \\
\text { mimics human } \\
\text { exposure during } \\
\text { adolescence by } \\
\text { continually exposing } \\
\text { nice to phthalate } \\
\text { from ages } 6 \text { to } \\
8 \text { weeks. }\end{array}$ & C57BL/6J mice & $\begin{array}{l}\text { 16S rRNA gene } \\
\text { sequencing and a } \\
\text { triple-quadrupole } \\
\text { time-of-flight } \\
\text { instrument coupled } \\
\text { to a binary pump } \\
\text { HPLC system. }\end{array}$ & $\begin{array}{c}\text { Oral probe di (2-ethylhexyl) } \\
\text { phthalate exposure increased } \\
\text { the abundance of } \\
\text { Lachnoclostridum, while } \\
\text { decreasing Akkermansia, } \\
\text { Odoribacter, and Clostridium } \\
\text { sensu stricto. }\end{array}$ & $\begin{array}{l}\text { Di (2-ethylhexyl) phthalate } \\
\text { exposure directly alters } \\
\text { microbiota therefore modifying } \\
\text { the production of bacterial } \\
\text { metabolites related to } \\
\text { neurodevelopmental disorders. }\end{array}$ \\
\hline
\end{tabular}


Table 2. Cont.

\begin{tabular}{|c|c|c|c|c|c|c|c|}
\hline References & Compound & Dose Exposure & $\begin{array}{l}\text { Justification of } \\
\text { Exposure Dose }\end{array}$ & Species Strain Mode & Methods & Outcomes & Conclusions \\
\hline $\begin{array}{l}\text { Gao et al. } \\
\text { (2017) [68] }\end{array}$ & Diazinon & $4 \mathrm{mg} / \mathrm{L}$ & $\begin{array}{l}\text { According to } \\
\text { previous studies, } \\
\text { dose that did not } \\
\text { elicit discernible } \\
\text { AChE inhibition. }\end{array}$ & C57BL/6 mice & $\begin{array}{l}\text { 16S rRNA gene } \\
\text { sequencing } \\
\text { and mass } \\
\text { spectrometry-based } \\
\text { metabolomics. }\end{array}$ & $\begin{array}{l}\text { Diazinon exposure significantly } \\
\text { disturbed the intestinal } \\
\text { microbiome, and the RNA } \\
\text { sequencing revealed that } \\
\text { diazinon exposure disrupts } \\
\text { the functional metagenome. } \\
\text { These changes were more } \\
\text { pronounced male mice. }\end{array}$ & $\begin{array}{l}\text { Diazinon exposure } \\
\text { disturbed the structure of } \\
\text { the gut microbiome, } \\
\text { the functional } \\
\text { metagenome and also had } \\
\text { a sexual } \\
\text { dysmorphic effect. }\end{array}$ \\
\hline $\begin{array}{l}\text { Jin et al. } \\
\text { (2015) [69] }\end{array}$ & Carbendazim & 100 or $500 \mathrm{mg} / \mathrm{kg}$ bw & $\begin{array}{l}\text { The exposure } \\
\text { concentration is } \\
\text { above the } \\
\text { maximum allowable } \\
\text { concentration of } \\
\text { carbendazim in food. }\end{array}$ & $\begin{array}{l}\text { ICR mice (Mus } \\
\text { musculus) }\end{array}$ & $\begin{array}{l}\text { Real time PCR } \\
\text { sequencing and } \\
\text { 16s rRNA } \\
\text { gene sequencing } \\
\text { and HPLC. }\end{array}$ & $\begin{array}{l}\text { Carbendazim exposure at } 100 \\
\text { and } 500 \text { mg kg led to } \\
\text { histopathological changes } \\
\text { in the liver, } \\
\text { disturbed lipid metabolism, } \\
\text { and intestinal gut dysbiosis. } \\
\text { During the first three days of } \\
\text { exposure to carbendazim the } \\
\text { most abundant constituents } \\
\text { of microbiomes, Firmicutes and } \\
\text { Bacteroidetes, tend to decrease. } \\
\text { From the fifth day of treatment } \\
\text { with carbendazim, Bacteroidetes } \\
\text { maintained the decreasing } \\
\text { tendency, but Firmicutes } \\
\text { started to increase. }\end{array}$ & $\begin{array}{l}\text { Exposure to carbendazim } \\
\text { disturbs microbiota and } \\
\text { can lead to inflammation, } \\
\text { which results in altered } \\
\text { lipid metabolism and } \\
\text { triggers obesity in } \\
\text { exposed mice. }\end{array}$ \\
\hline $\begin{array}{l}\text { Liang et al. } \\
\text { (2019) [70] }\end{array}$ & Chlorpyrifos & $5 \mathrm{mg} / \mathrm{kg}$ & $\begin{array}{l}\text { Concentration higher } \\
\text { than NOAEL. }\end{array}$ & C57Bl/6 and CD-1 mice & $\begin{array}{c}16 \mathrm{~S} \text { rRNA } \\
\text { gene sequencing } \\
\text { and qPCR. }\end{array}$ & $\begin{array}{l}\text { Exposure to chlorpyrifos in mice } \\
\text { induced changes in microbiota, } \\
\text { increased body weight, } \\
\text { and lowered insulin sensitivity. } \\
\text { Chlorpyrifos also resulted in } \\
\text { disruption of the intestinal barrier } \\
\text { and more, which led to the entry } \\
\text { of lipopolysaccharides in the } \\
\text { body, which promote the release } \\
\text { of pro-inflammatory factors. }\end{array}$ & $\begin{array}{l}\text { Chlorpyrifos exposure } \\
\text { might contribute to the } \\
\text { worldwide epidemic of } \\
\text { inflammatory diseases. }\end{array}$ \\
\hline
\end{tabular}


Table 2. Cont

\begin{tabular}{|c|c|c|c|c|c|c|c|}
\hline References & Compound & Dose Exposure & $\begin{array}{l}\text { Justification of } \\
\text { Exposure Dose }\end{array}$ & $\begin{array}{l}\text { Species Strain } \\
\text { Mode }\end{array}$ & Methods & Outcomes & Conclusions \\
\hline $\begin{array}{l}\text { Liu et al. } \\
\text { (2017) [71] }\end{array}$ & $\begin{array}{l}\mathrm{p}, \mathrm{p}^{\prime} \text {-dichlorodiphenyldichloroethylene(p, } \mathrm{p}^{\prime} \text {-DDE) } \\
\text { and } \beta \text {-hexachlorocyclohexane }(\beta-\mathrm{HCH})\end{array}$ & $\begin{array}{l}1 \mathrm{mg} \text { p, } \mathrm{p}^{\prime}-\mathrm{DDE} / \mathrm{kg} \\
\text { bw/day and } 10 \mathrm{mg} \\
\beta-\mathrm{HCH} / \mathrm{kg} \text { bw/day }\end{array}$ & $\begin{array}{l}\text { These doses } \\
\text { mimic the } \\
\text { chronic exposure } \\
\text { in human. }\end{array}$ & C57BL/6 mice & $\begin{array}{l}16 \mathrm{~S} \text { rRNA } \\
\text { gene sequencing, } \\
\text { real time PCR } \\
\text { and UPLC-M. }\end{array}$ & $\begin{array}{l}\text { Exposure to organochlorines } \\
\text { disturbed the abundance and } \\
\text { composition of gut microbiota } \\
\text { (increased Lactobacillus } \\
\text { capable of deconjugating } \\
\text { bile salts). This affects the } \\
\text { hydrophobicity and } \\
\text { composition of bile acids, } \\
\text { down-regulates the } \\
\text { expression of genes involved } \\
\text { in the reabsorption of bile } \\
\text { acids in the distal ileum, } \\
\text { and up-regulates the } \\
\text { expression of genes involved } \\
\text { in the hepatic synthesis of } \\
\text { bile acids. }\end{array}$ & $\begin{array}{l}\text { Chronic exposure to low } \\
\text { doses of organochlorines } \\
\text { increases the risk of } \\
\text { dysfunction in bile } \\
\text { acid metabolism. }\end{array}$ \\
\hline $\begin{array}{l}\text { Tu et al. } \\
\text { (2019) [72] }\end{array}$ & 2,4-Dichlorophenoxyacetic acid (2, 4-D) & $<15 \mathrm{mg} / \mathrm{kg}$ bw/day & $\begin{array}{l}\text { Concentration lower } \\
\text { than NOAEL. }\end{array}$ & C57BL/6 mice & $\begin{array}{l}16 \mathrm{~S} \text { rRNA } \\
\text { gene sequencing } \\
\text { and LC-MS. }\end{array}$ & $\begin{array}{l}\text { Metagenomic results revealed } \\
\text { a distinct intestinal } \\
\text { microbiota with changes in } \\
\text { various microbial metabolic } \\
\text { pathways, including urea } \\
\text { degradation, and amino acid } \\
\text { and carbohydrate } \\
\text { metabolism. }\end{array}$ & $\begin{array}{l}\text { 2,4-D exposure resulted in } \\
\text { changes in the } \\
\text { composition and activity } \\
\text { of gut microbiota. The } \\
\text { metabolic profile of host } \\
\text { plasma samples showed } \\
\text { changes in the metabolic } \\
\text { profiles indicative of 2,4-D } \\
\text { toxicity at low doses. }\end{array}$ \\
\hline $\begin{array}{l}\text { Yang et al. } \\
\text { (2019) [73] }\end{array}$ & Organophosphorus: diethyl phosphate (DEP) & 0.08 or $0.13 \mathrm{mg} / \mathrm{kg}$ & 1/500 LD50. & Wistar rats & $\begin{array}{l}\text { NanoDrop } \\
\text { spectrophotometer } \\
\text { and 16S rRNA } \\
\text { gene sequencing. }\end{array}$ & $\begin{array}{l}\text { Exposure to high dose of DEP } \\
\text { promotes the growth of } \\
\text { butyrate-producing bacterial } \\
\text { genera Alloprevotella and } \\
\text { Intestinimonas, which } \\
\text { induced an increase in } \\
\text { estradiol and a decrease in } \\
\text { total triglycerides and low } \\
\text { density lipoprotein cholesterol. } \\
\text { Exposure to DEP also } \\
\text { increased tyrosine-tyrosine } \\
\text { peptide and ghrelin, } \\
\text { attributed to the enrichment } \\
\text { of Clostridium sensu stricto } 1 \\
\text { and Lactobacillus, producers of } \\
\text { short-chain fatty acids. }\end{array}$ & $\begin{array}{c}\text { Chronic exposure to DEP } \\
\text { affected the } \\
\text { gut microbiota, } \\
\text { serum hormones, } \\
\text { and proinflammatory } \\
\text { cytokines in rats, } \\
\text { with stronger responses } \\
\text { observed at high doses. }\end{array}$ \\
\hline
\end{tabular}


Table 2. Cont

\begin{tabular}{|c|c|c|c|c|c|c|c|}
\hline References & Compound & Dose Exposure & $\begin{array}{l}\text { Justification of } \\
\text { Exposure Dose }\end{array}$ & $\begin{array}{l}\text { Species Strain } \\
\text { Mode }\end{array}$ & Methods & Outcomes & Conclusions \\
\hline $\begin{array}{l}\text { Wu et al. } \\
\text { (2018) [74] }\end{array}$ & Propamocarb & $\begin{array}{c}0,0.5,5,50 \mathrm{mg} / \mathrm{kg} \\
\text { bw/day }\end{array}$ & $\begin{array}{l}\text { Dosages set } \\
\text { according to the } \\
\text { highest residue } \\
\text { from the EU-MRLs } \\
\text { and the NOAEL or } \\
\text { long term toxicity. }\end{array}$ & Mice & $\begin{array}{c}16 \mathrm{~S} \text { rRNA } \\
\text { gene sequencing. }\end{array}$ & $\begin{array}{l}\text { Exposure to propamocarb } \\
\text { disturbed the transcription of } \\
\text { liver genes related to } \\
\text { regulation of } \\
\text { lipid metabolism. } \\
\text { The microbiota in the cecal } \\
\text { content and feces changed at } \\
\text { the phylum or gender level. }\end{array}$ & $\begin{array}{l}\text { Exposure to high dose } \\
\text { propamocarb changes the } \\
\text { metabolism of mice by } \\
\text { altering the gut microbiota } \\
\text { and microbial metabolites. }\end{array}$ \\
\hline $\begin{array}{l}\text { Gao et al., } \\
\text { (2017) [75] }\end{array}$ & Triclosan (TCS) & $2 \mathrm{ppm}$ & $\begin{array}{l}\text { The concentration } \\
\text { used is } 100 \text { times } \\
\text { lower than that } \\
\text { which can } \\
\text { promote liver } \\
\text { carcinogenesis. }\end{array}$ & C57BL/6 mice & $\begin{array}{l}16 \mathrm{~S} \text { rRNA } \\
\text { gene sequencing } \\
\text { and shotgun } \\
\text { metagenomics } \\
\text { sequencing. }\end{array}$ & $\begin{array}{c}\text { Exposure to TCS produced } \\
\text { significant changes in mouse } \\
\text { gut bacterial } \\
\text { community assembly. } \\
\text { Metagenomic sequencing } \\
\text { showed an increase in gut } \\
\text { bacterial genes related to } \\
\text { triclosan resistance, } \\
\text { stress response, } \\
\text { and antibiotic resistance, } \\
\text { and others. }\end{array}$ & $\begin{array}{l}\text { Exposure to TCS alters the } \\
\text { intestinal microbiome of } \\
\text { mice by inducing changes } \\
\text { at the compositional and } \\
\text { functional levels. }\end{array}$ \\
\hline $\begin{array}{l}\text { Gaulke et al. } \\
\text { (2016) [76] }\end{array}$ & TCS & $100 \mu \mathrm{g} / \mathrm{g}$ & $\begin{array}{c}\text { Dose to } \\
\text { cause endocrine } \\
\text { disruption in fish. }\end{array}$ & Zebrafish & $\begin{array}{c}16 \mathrm{~S} \text { rRNA } \\
\text { gene sequencing. }\end{array}$ & $\begin{array}{l}\text { Operational taxonomic units } \\
\text { of the Enterobacteriaceae family } \\
\text { are susceptible to } \\
\text { TCS exposure, } \\
\text { but operational taxonomic } \\
\text { units of the Pseudomonas genus } \\
\text { are more resistant } \\
\text { to exposure. }\end{array}$ & $\begin{array}{l}\text { Exposure to TCS } \\
\text { promotes changes in the } \\
\text { composition and } \\
\text { ecological dynamics of gut } \\
\text { microbial communities. }\end{array}$ \\
\hline $\begin{array}{l}\text { Kennedy et al. } \\
\text { (2016) [77] }\end{array}$ & $\begin{array}{c}\text { TCs (TCS and } \\
\text { Triclocarban (TCC)) }\end{array}$ & $0.1 \%(v / v)$ & $\begin{array}{c}\text { According to } \\
\text { blood human level. }\end{array}$ & $\begin{array}{l}\text { Timed-pregnant } \\
\text { Sprague Dawley } \\
\text { (SD) rats }\end{array}$ & $\begin{array}{l}\text { 16s rRNA } \\
\text { gene sequencing. }\end{array}$ & $\begin{array}{l}\text { TCC exposure reduced the } \\
\text { diversity of fecal microbiota } \\
\text { in exposed rats versus } \\
\text { controls at } 7 \text { days } \\
\text { after exposure. } \\
\text { This continued throughout } \\
\text { perinatal exposure. }\end{array}$ & $\begin{array}{c}\alpha \text {-diversity was reduced } \\
\text { in exposed animals at all } \\
\text { sampling time points after } \\
\text { baseline. Differences in } \\
\beta \text {-diversity were found } \\
\text { between gestational day } \\
18 \text { and post-delivery day } \\
16 \text { in exposed versus } \\
\text { control dams. }\end{array}$ \\
\hline
\end{tabular}


Table 2. Cont

\begin{tabular}{|c|c|c|c|c|c|c|c|}
\hline References & Compound & Dose Exposure & Justification of Exposure Dose & Species Strain Mode & Methods & Outcomes & Conclusions \\
\hline $\begin{array}{l}\text { Ma et al. } \\
\text { (2020) [78] }\end{array}$ & TCS & 0,10, or $50 \mathrm{mg} / \mathrm{kg}$ & $\begin{array}{l}\text { Doses referenced previous toxicity } \\
\text { studies in rats (Lowest toxic dose in rats } \\
\text { is } 50 \mathrm{mg} / \mathrm{kg} / \text { day) }\end{array}$ & Rats & $\begin{array}{c}16 \mathrm{~S} \text { rRNA } \\
\text { gene sequencing. }\end{array}$ & $\begin{array}{l}\text { Exposure to TCS reduced } \\
\text { diversity and altered the } \\
\text { microbiota composition at } \\
\text { doses of } 50 \mathrm{mg} / \mathrm{kg} / \text { day in } \\
\text { adult rats and at two doses in } \\
\text { old rats. These changes were } \\
\text { long-lasting even after the } \\
\text { exposure was terminated and } \\
\text { accumulated over time, } \\
\text { inducing metabolic disorders } \\
\text { in old rat offspring. }\end{array}$ & $\begin{array}{c}\text { Exposure to TCS early in } \\
\text { life results in long-lasting } \\
\text { changes in the metabolism } \\
\text { and intestinal microbiota } \\
\text { and they accumulate } \\
\text { over time. }\end{array}$ \\
\hline $\begin{array}{l}\text { Narrowe et al. } \\
\text { (2015) [79] }\end{array}$ & TCS & 100 to $1000 \mathrm{ng} / \mathrm{l}$ & Environmentally relevant concentrations & $\begin{array}{l}\text { Larval fathead minnows } \\
\text { (Pimephales promelas) }\end{array}$ & $\begin{array}{l}\text { High-throughput } \\
16 \mathrm{~S} \text { rRNA } \\
\text { sequencing }\end{array}$ & $\begin{array}{l}\text { TCS resulted in an increase of } \\
\text { all members of the order } \\
\text { Pseudomonadales, in five } \\
\text { Acinetobacter OTUs, and in } 26 \\
\text { OTUs (Flavobacterium, } \\
\text { Chryseobacterium, } \\
\text { and Shewanella) at day } 7 .\end{array}$ & $\begin{array}{l}\text { Short-term, low-level } \\
\text { environmental exposure } \\
\text { to TCS is sufficient to } \\
\text { disrupt gut microbiome in } \\
\text { minnows. }\end{array}$ \\
\hline $\begin{array}{l}\text { Zang et al. } \\
\text { (2019) [80] }\end{array}$ & TCS & $0.002 \%(v / v)$ & Based on previous studies & Zebrafish (Danio rerio) & $\begin{array}{l}\text { 16S rRNA gene } \\
\text { sequencing and } \\
\text { qRT-PCR }\end{array}$ & $\begin{array}{l}\text { TCS exposure led to severe } \\
\text { structural and morphologic } \\
\text { damage to the intestines, } \\
\text { spleen, and kidney observed } \\
\text { in histopathologic studies. } \\
\text { Lactobacillus was able to } \\
\text { mitigate this damage. }\end{array}$ & $\begin{array}{l}\text { Lactobacillus plantarum } \\
\text { ST-III increases gut } \\
\text { microbial biodiversity in } \\
\text { zebrafish and mitigates } \\
\text { the damages associated } \\
\text { with TCS exposure. }\end{array}$ \\
\hline
\end{tabular}

NOAEL: no observed adverse effects level; LOAEL: lowest observed adverse effect level; MRL: maximum residues levels. 
Table 3. Effects of endocrine disruptors on the human microbiota.

\begin{tabular}{|c|c|c|c|c|c|c|}
\hline References & Compound & Exposure Route & Species Strain Mode & Methods & Outcomes & Conclusions \\
\hline $\begin{array}{l}\text { Eggers et al. } \\
\text { (2019) [81] }\end{array}$ & Metals (lead) & Environmental (food) & Adult humans & $\begin{array}{l}\text { DNA sequencing of } \\
\text { the } 16 \mathrm{~S} \text { rRNA } \\
\text { V4 region }\end{array}$ & $\begin{array}{c}\text { Increased urine Pb levels were associated } \\
\text { with the presence of Proteobacteria, increased } \\
\alpha \text {-diversity }(p=0.071), \\
\text { and wealth }(p=0.005) \text {. Changes in } \\
\beta \text {-diversity were significantly } \\
\text { associated }(p=0.003) \text { with differences in } \\
\text { Pb levels. }\end{array}$ & $\begin{array}{l}\mathrm{Pb} \text { exposure is associated with diversity } \\
\text { and compositional changes of intestinal } \\
\text { microbiota in adults. }\end{array}$ \\
\hline $\begin{array}{l}\text { Wu et al. } \\
\text { (2016) [82] }\end{array}$ & Phytoestrogen & Oral (diet) & Adult humans & $\begin{array}{l}\text { 16S rRNA-tagged } \\
\text { sequencing and } \\
\text { plasma and urinary } \\
\text { metabolomic platforms }\end{array}$ & $\begin{array}{c}\text { Consumption of fermentable substrates was } \\
\text { not associated with higher levels of } \\
\text { short-chain fatty acids in fecal samples } \\
\text { in vegans. }\end{array}$ & $\begin{array}{l}\text { Despite the differences in plasma } \\
\text { metabolome between vegans with high } \\
\text { soy consumption and omnivores, } \\
\text { the gut microbiota in the two groups } \\
\text { was similar. }\end{array}$ \\
\hline $\begin{array}{c}\text { Yang et al. (2019) } \\
\text { [83] }\end{array}$ & $\begin{array}{c}\text { Phthalates } \\
\text { (Di(2-ethylhexyl) } \\
\text { phthalate) }\end{array}$ & Intravenous (plastic) & Newborns & $\begin{array}{l}\text { Water ACQUITY } \\
\text { UPLC and MS/MS; } \\
\text { 16S rRNA sequencing }\end{array}$ & $\begin{array}{c}\text { Biota differences were found between } \\
\text { meconium samples and fecal samples } \\
\text { collected later. Di(2-ethylhexyl) } \\
\text { phthalate-exposed microbiota showed } \\
\text { higher variability of bacteria taxa. }\end{array}$ & $\begin{array}{l}\text { Short-term di(2-ethylhexyl) phthalate } \\
\text { exposure led to temporary gut dysbiosis } \\
\text { This suggests that long-term exposure } \\
\text { may result in permanent gut dysbiosis. } \\
\text { Di(2-ethylhexyl) phthalate levels did not } \\
\text { alter the dominant bacterial phyla } \\
\text { composition, but the } \\
\text { Firmicutes-Bacteroidetes ratio changed } \\
\text { over time in both exposed and } \\
\text { unexposed newborns. }\end{array}$ \\
\hline $\begin{array}{l}\text { Stanaway et al. } \\
\text { (2017) [84] }\end{array}$ & azinphos-methyl & Oral and inhalation & Adult men & $\begin{array}{c}\text { Isotope dilution } \\
\text { GC-HR-MS, } \\
\text { 16S rRNA gene DNA } \\
\text { sequenced and } \\
\text { Agencourt AMPure } \\
\text { XP PCR } \\
\text { purification system } \\
\end{array}$ & $\begin{array}{c}\text { Disturbances in Streptococcus, Micrococcineae, } \\
\text { Gemella, Haemophilus, Halomonas, } \\
\text { Actinomycineae, and Granulicatell were } \\
\text { observed, and decreased oral bacterial } \\
\text { genus Streptococcus. }\end{array}$ & $\begin{array}{l}\text { Human exposure to agricultural } \\
\text { pesticides is associated with the } \\
\text { alteration of oral microbiota, but future } \\
\text { research is needed to support } \\
\text { these findings. }\end{array}$ \\
\hline $\begin{array}{c}\text { Bever et al. (2018) } \\
\text { [85] }\end{array}$ & TCS & Oral (breast milk) & Infants and Mothers & $\begin{array}{l}16 \mathrm{~S} \text { rRNA sequencing } \\
\text { and GC-MS }\end{array}$ & $\begin{array}{l}\text { Diversity in fecal microbiome of } \\
\text { TCS-exposed infants versus unexposed } \\
\text { infants differed }\end{array}$ & $\begin{array}{l}\text { Exogenous chemicals are correlated with } \\
\text { disturbances in microbiome diversity in } \\
\text { the intestinal community of infants } \\
\text { during the early developing period. }\end{array}$ \\
\hline $\begin{array}{l}\text { Ribado et al. } \\
\text { (2017) [86] }\end{array}$ & TCs (TCS and TCC) & Dermal (personal care products) & Infants and Mothers. & 16s rRNA sequencing & $\begin{array}{l}\text { TC exposure was not associated with a } \\
\text { reduction of gut microbiota diversity in } \\
\text { mothers and their infants at any of three } \\
\text { time points after birth. Shannon's diversity } \\
\text { index was not decreased in infants } \\
\text { randomized to TC-containing products. }\end{array}$ & $\begin{array}{l}\text { After } 10 \text { months, chronic TC exposure } \\
\text { from household products does not } \\
\text { contribute to recovery of gut } \\
\text { microbiomes in mothers or their infants } \\
\text { The most abundant species in the } \\
\text { unexposed infants, } B \text {. fragilis, is } \\
\text { associated with direct maturation of the } \\
\text { immune system and the production of } \\
\text { anti-inflammatory polysaccharides. }\end{array}$ \\
\hline
\end{tabular}


Exposure to BPA resulted in a fast onset of T1D in female mice and slow onset in male mice. Subacute BPA exposure in female mice resulted in increased Bacteroidetes and Cyanobacteria and decreased Firmicutes, Tenericutes, and Proteobacteria. Chronic exposure to BPA in females also resulted in a proinflammatory gut microbiota, with a decrease in Bacteroidales and Lactobacillus. These results are consistent with human epidemiological studies, which show that the gut microbiota in individuals with T1D is dominated by Bacteroidetes at the phylum level and in turn with a reduction in Firmicutes in relation to control [87]. In male mice, BPA exposure results in a slow onset of T1D. Subacute exposure caused a decrease in Bacilli at the class level, which is in accordance with the findings reported in human epidemiological studies on the association between the the development of T1D and gut microbiota composition [88]. Additionally, chronic exposure to BPA in males resulted in decreased Lachnospiraceae, which has been shown to promote T1D in NOD mice models [89].

Using their NOD mouse model, Xu et al. (2019) [6] showed that BPA's effects on the development of T1D were related to host age and gender, following various windows of exposure. Exposed juvenile NOD females (starting postnatal day (PND) 28 to PND56) and NOD offspring (starting gestation day 5 to PND28) were exposed perinatally to BPA by dosing the dams to 0 or $30 \mu \mathrm{g} / \mathrm{kg}$ BW. Adult NOD females were exposed to 0 or $300 \mu \mathrm{g} / \mathrm{kg}$ bw. Interestingly, BPA increased the risk of developing T1D in adult and juvenile females, which was related to changes in the gut microbiota, but the female offspring showed a reduced risk of developing T1D. In contrast, BPA had insignificant effects on the development of T1D in the male offspring. The changes in the gut microbiota of juvenile females associated with BPA exposure included, at the genus level, an increase of Turicibacter, Oscillospira, Ruminococcus, Jeotgalicoccus, and Lachnospiraceae, which increase the risk of T1D and inflammation, as shown in several animal models [89-91].

Malaisé et al. (2017) [5], in their longitudinal study, found that the perinatal exposure of C3H/HeN mice to BPA at $50 \mu \mathrm{g} / \mathrm{kg}$ bw/day (100 times lower the no observed adverse effect level (NOAEL), $5 \mathrm{mg} / \mathrm{kg}$ bw/day) induced dysbiosis and systemic immune imbalances at PND45. These effects were associated with a rise in glucose intolerance and a decrease in IgA and Bifidobacteria in the feces. Some strains of the Bifidobacterium genus have been shown to have anti-inflammatory properties [92].

Javurek et al. (2016) [31] explored the changes in gut microbiota related to BPA exposure in parents and their offspring in California mice (Peromyscus californicus). Female and male monogamous and biparental mice were exposed to BPA ( $50 \mathrm{mg} / \mathrm{kg}$ feed weight) from periconception to weaning. The dose selected has been shown to induce metabolic alterations and it is below the diet-administered

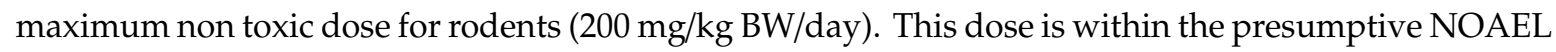
and results in concentrations similar to those reported in human serum. They demonstrated for the first time that parental exposure to concentrations of BPA environmentally relevant causes changes in the microbiota structure in non-exposed offspring. These changes were generational- and sex-dependent. In this respect, they reported that BPA (and ethinyl estradiol) exposure induced an increase in Akkermansia, Mollicutes, Prevotellaceae, Bacteroides, Erysipelotrichaceae, Methanobrevibacter, Sutterella in parents and offspring. These species have been associated to inflammatory bowel disease, obesity and metabolic disorders [93,94], autism spectrum disorders [95], colon cancer [96], and other conditions. However, Bifidobacterium was also found in higher amounts in fecal samples of female offspring. Some Bifidobacterium strains have been shown to exert health-promoting effects and is included in a number of probiotic foods and supplements [97]. DeLuca et al. (2018) [46] used a dextran sulphate sodium-induced colitis model in female C57BL/6 mice and found that BPA exposure at $50 \mu \mathrm{g} / \mathrm{kg} /$ day negatively affects gut physiology by reducing microbiota metabolites derived from aromatic amino acids, which might be associated with autoimmune diseases, specifically with inflammatory bowel disease. This dose was selected because it is the EPA reference dose for BPA.

Lai et al. (2016) [48] used 16S rRNA gene sequencing of cecal microbiota of CD-1 male mice to analyse the effects of dietary BPA intake on microbiota composition and physiology. Mice on high-fat high-sucrose diet were the positive controls. The findings showed that dietary BPA exposure was related to a decrease in the diversity of microbiota species. The structural changes of the gut microbiota 
exposed to dietary BPA were similar to those found in mice on high-fat high-sucrose diets. Additionally, the comparison between BPA and high-fat diet revealed an increase in Proteobacteria in both groups. The increased abundance of Proteobacteria has been related to different conditions such as metabolic disorders and inflammatory bowel disease [98]. Lastly, exposure to dietary BPA produced a decrease in the phylum Firmicutes, with most of the 16SRNA sequencing corresponding to the class Clostridia. Interestingly, Larsen et al. (2010) [23] demonstrated a significant reduction in Firmicutes and Clostridia in the feces of human male adults with T2D compared to the healthy group.

Dietary exposure to BPA also modified the gut microbiota in zebrafish [30,32]. In a study conducted by Liu et al. (2016) [32], the authors concluded that exposure to BPA resulted in an increase of the phylum CKC4 in both sexes probably connected to changes in the host lipid metabolism (increased triglycerides in the muscle). However, one of the limitations of this study was that the functional study of CKC4, a phylum included in the SILVA database, was very incomplete.

Chen et al. (2018) [30] exposed adult zebrafish at BPA doses of 0, 2 and $20 \mu \mathrm{g} / \mathrm{L}$, titanium dioxide nanoparticles (nano- $\mathrm{TiO}_{2}$ ) and their binary mixtures for three months. Exposure to both compounds resulted in changes in the gut microbiota. An antagonistic interaction was observed at low BPA concentrations, but a synergistic interaction was observed at high BPA concentrations. Zebrafish growth and gut health (oxidative stress, barrier function, inflammation) were associated with sex and concentration of chemicals. Additionally, zebrafish weight was found to be positively associated with the presence of Bacteroides, closely related to the Anaerococcus, Finegoldia, and Peptoniphilus genera.

The work by Reddivari et al. (2017) [49] showed that perinatal exposure to BPA in Dutch-Belted rabbits $(200 \mu \mathrm{g} / \mathrm{kg}$ bw/day) induced an increase in the Methanobrevibacter spp community leading to inflammation of the colon and liver, and increased gut permeability in the offspring demonstrated by increased levels of serum lipopolysaccharide. This study used rabbits as an animal model because this species has an extensive infantile period of development similar to that of humans and utilized BPA at a relatively low dose level of $200 \mathrm{~g} / \mathrm{kg} \mathrm{bw} /$ day (approximately $1 / 25$ of the NOAEL dose). Significant positive correlations were observed between increased Methanobrevibacter spp. in the colon and systemic concentrations of lipopolysaccharide $\left(r^{2}=0.67 ; p=0.023\right)$. This species can metabolize dietary substrates that lead to increased host energy intake and weight gain [93]. Lastly, perinatal exposure to BPA led to a reduction of the diversity of the microbial communities and their metabolites (short chain fatty acids) and to an increase in intestinal permeability.

The work by Koestel et al. (2017) [47] showed that the circulating BPA levels in dogs fed with canned dog food for two weeks $(2.2 \pm 0.15 \mathrm{ng} / \mathrm{mL})$ were similar to the levels found in humans [99], with higher BPA concentrations related to modifications in the composition of the microbiome. These changes may lead to modifications in metabolic pathways, including the capacity to metabolize bisphenols. In this study, higher serum BPA levels were associated with decreasing relative abundances of Bacteroides spp., which may result in a reduction of BPA bacterial degradation.

We found only one study of the effects of BPA analogs on the microbiota. Catron et al. (2019) [29] exposed zebrafish during their developmental period to BPA, BPAF, BPB, BPF, and BPS at different concentrations. These concentrations were selected based on zebrafish toxicity data available through the ICSS ToxCast dashboard and previous zebrafish studies. 16S rRNA gene sequencing showed that structural microbiota disruption was highly dependent on concentration and that exposure to BPS, BPA, or BPF caused the enrichment of the microbial functions, but this did not occur with exposure to BPB or BPAF. Lastly, microbial disruption was inversely associated with host developmental toxicity and estrogenicity. The main finding of this work was that BPS, BPA, and BPF produced disruptions in microbial composition, occurring throughout the critical window of early development, at concentrations that did not cause evident developmental toxicity.

\subsubsection{Pesticides}

The adverse effects of agricultural pesticides derived from their endocrine disruptive activity that may affect the thyroid and the reproductive, nervous, and adipose systems were investigated [100-102]. 
In vitro studies have demonstrated that different pesticides can cause gut dysbiosis [38-41], using the chicken microphrobiome [39] and the Rumen Simulation Technique (RUSITEC) system [40,41]. Joly et al. (2013) [38] studied the impact of in vitro exposure to low doses of organophosphorus chloropyrifos in a SHIME system, and the effects in vivo in pregnant Wistar rats. Their results showed that exposure to chlorpyrifos induces the proliferation of Bacteroides spp. and Enterococcus spp. and reduces the proliferation of Bifidobacterium spp. and Lactobacillus spp.

Three studies in rodents (in ICR, C57Bl/6, and CD-1 mice and Wistar rats) showed that exposure to pesticides (carbendazim, chlorpyrifos, and organophosphorus pesticides) induces dysbiosis in the microbiota and inflammation, leading to an alteration of lipid metabolism and triggering obesity in exposed rodents $[69,70,73]$.

Wu et al. (2018) [74] evaluated the effects of exposure to propamocarb (3, 30, and $300 \mathrm{mg} / \mathrm{L}$ for 28 days) in five week-old male Institute of Cancer Research mice. These concentrations were established based on the highest residue from the EU-Maximum Residues levels and the long-term toxicity NOAEL ( $20 \mathrm{mg} / \mathrm{kg}$ bw/day) [103]. The authors found that exposure induced the disruption of the transcription of hepatic genes involved in the regulation of lipid metabolism. The cecal and fecal microbiota changed at the phylum or genus levels.

Liu et al. (2017) [71] exposed adult male C57BL/6 mice, over eight weeks, to low dose $\mathrm{p}, \mathrm{p}^{\prime}$-dichlorodiphenyldichloroethylene $(1 \mathrm{mg} / \mathrm{kg}$ body weight/day) and $\beta$-hexachlorocyclohexane $(10 \mathrm{mg} / \mathrm{kg}$ body weight/day), which are similar to the levels found in chronic exposure in humans. The authors found that exposure induced changes in the composition of the gut microbiota, particularly leading to higher abundances of Lactobacillus that are capable of deconjugating bile acids by bile salt hydrolases. These transformation reactions affect the hydrophobicity and composition of bile acids, and down-regulate the expression of genes involved in the reabsorption of bile acids in the distal ileum, but up-regulate the expression of genes involved in the hepatic synthesis of bile acids.

Tu et al. (2019) [72] evaluated the toxic effects of exposure to 2,4-dichlorophenoxyacetic acid, at an occupationally important dose, on the intestinal microbiota of specific-pathogen-free C57BL/6 male mice. Metagenomic sequencing showed a distinct gut microbial community with disturbances in the pathways of amino acid and carbohydrate metabolism and urea degradation. These findings are of particular interest, as evidence has showed that modifications of microbiome-related pathways and metabolites would produce an alteration of gut-host homeostasis, which may increase the risk of diseases [104].

The sexual dysmorphic effects of pesticide exposure have been described in animal models. Gao et al. (2017) [68] showed that exposure to a low dose of organophosphorus pesticide diazinon $(4 \mathrm{mg} / \mathrm{L}$ in drinking water) modifies the gut microbiota composition and functionality in C57BL/6 mice, with more impact in male mice. At the phylum level, Bacteroidetes increased by 1.8-fold, while Firmicutes decreased by 1.8-fold, in diazinon exposed males compared to controls. As shown previously, a high Firmicutes/Bacteroidetes ratio is related to obesity, which is consistent with the observed decrease of body weight in male mice. By contrast, no effects of diazinon exposure on body weight and the Firmicutes/Bacteroidetes ratio were observed in female mice.

Finally, an epidemiological study in humans carried out by Stanaway et al. (2017) [84] found that exposure to agricultural pesticides can cause dysbiosis of the human oral microbiota. A cohort of 65 agricultural workers and 52 non-agricultural workers was studied. The results showed that workers exposed to azinfos-methyl had a decrease in common genera found in the human oral microbiome (Streptococcus, Micrococcineae, Gemella, Haemophilus, Halomonas, Actinomycineae, and Granulicatella). Although more studies are needed to confirm the results of Stanaway et al. (2017) [84], the data obtained indicate that the oral microbiome could be used as a simple biomarker for assessing pesticide exposure in epidemiological studies. 


\subsubsection{Polychlorinated Biphenyls}

Polychlorinated biphenyls (PCBs) are well-known EDCs that were massively used until the mid-1970s as insulators for electrical equipment such as transformers, switches, capacitors, and thermostats. Despite the current ban on manufacturing, PCBs continue to be a common environmental contaminant because of their accidental and intentional release in large quantities due to their long-term stability $[105,106]$. The main route of exposure to PCBs is the consumption of contaminated foods such as fish and shellfish. PCBs have been related to hormone-dependent cancers, an impaired reproductive system, and cognitive and metabolic disorders (such as impaired glucose metabolism and adipocyte inflammation) $[107,108]$.

The available evidence has shown the detrimental effects of PCB exposure on the microbiota that can trigger host metabolic disorders [36,50-55,109]. Exposure to PCBs promotes an altered microbiome, with reduced Proteobacteria [53], decreases in microbial diversity, and an increased Bacteroidetes-to-Firmicutes ratio, usually linked to intestinal and systemic inflammation [55]. In addition, changes in bile acid homeostasis that result in dysbiosis have been described in adult mice exposed to a PCB mixture [51]. Other studies have also reported the impact of exposure to PCB on amphibian [54] and zebrafish microbiomes [50]. Recently, Rude et al. (2019) [56] reported that developmental exposure to PCBs induces dysbiosis and epithelial permeability defects in the ileum and colon that result in changes to the microbial $\beta$-diversity of juvenile mice.

Petriello et al. (2018) [55] found that exposure to PCB126 (1 mmol/ $\mathrm{kg})$ induces disruption of the gut microbiota and host metabolism in seven week-old male Ldlr $-/-$ mice, which are a model of cardiometabolic disease. This PCB126 dose was selected because it results in plasma concentrations similar to those found in human exposure [110]. The 16S rRNA sequencing revealed changes at the phylum and genus levels, and consistent increases in intestinal and systemic inflammation. The Firmicutes/Bacteroidetes ratio was increased after PCB126 exposure. This increase has been consistently linked to obesity, insulin resistance, inflammation, and other alterations of host metabolism [111]. Additionally, a strong PCB-dependent association was found between Bifidobacterium and circulating glucagon-like peptide-1.

Chi et al. 2019 [52] exposed adult female C57BL/6 mice to environmentally relevant low-dose PCB126 $(50 \mu \mathrm{g} / \mathrm{kg} \mathrm{bw})$ once per week over six weeks and found that chronic low-dose exposure promoted dysbiosis, with changes to the microbiota's structure and composition. In addition, PCB126 promoted dyslipidemia, hepatic damage, and a fatty liver. Lastly, metabolic indicators of these conditions seem to positively correlate with specific bacterial taxa.

The study by Chen et al. (2018) [50] showed that the exposure of zebrafish to model pollutants with different mechanisms of action and different affinities to estrogen and aryl hydrocarbon receptors (atrazine, estradiol, PCB126, and PCB153) at $1.0 \mu \mathrm{g} / \mathrm{L}$ for seven days resulted in changes to the microbiota and in the deterioration of intestinal and hepatic functions. The authors reported that aryl hydrocarbon and estrogen receptor signaling regulate gut microbiota physiology. Data showed that impaired Aeromonas reproduction was significantly related to oxidative damage, especially in the PCB126 groups. Previous research has linked Aeromonas spp. to intestinal inflammation and soft tissue infection [112].

\subsubsection{Parabens}

Parabens are widely used as preservatives and bactericides in pharmaceuticals, personal care products, and some food products [113-115]. Several studies have reported on the adverse health effects of parabens, including their endocrine disrupting and obesogenic activities [116-119]. However, there are few data available regarding the effects of parabens on the microbiota.

In this respect, Hu et al. (2016) [66] analyzed the effect of low-dose exposure to methylparaben, triclosan, and diethylphthalate and their mixtures, as well as the window of susceptibility, in Sprague-Dawley rats. The doses investigated result in urinary biomarker levels similar to those 
observed in humans [120]. The Bacteroidetes phylum was increased, while the growth of Firmicutes was decreased in all exposed rats compared to controls. However, Betaproteobacteria was increased only in the methylparaben and mixture groups, suggesting that exposure to paraben mixtures produces a distinct microbiome shift different from that resulting from individual chemicals or from simple additive effects. Surprisingly, these differences decreased in adulthood. In addition, a reduction in body weight in rats exposed during adolescence was observed [66]. This is consistent with other studies reporting a decrease in the Bacteroidetes phylum and an increase in Firmicutes, linked to weight gain $[121,122]$. These studies highlight i) the importance of studying the critical window of exposure such as adolescence; ii) the effect of low dose exposure, similar to a human exposure scenario; and iii) the need to evaluate the combined effect of multiple exposures. Obadia et al. (2018) [65] observed that exposure to methylparaben $(0.1 \%$ and $0.3 \%)$ in fly medium reduces microbiota growth and modifies the composition and amount of the bacteria and yeasts in the intestine of the Drosophila fly.

The effects of parabens on the microbiota need further research, as their interactions are poorly understood.

\subsubsection{Phytoestrogens}

Phytoestrogens are compounds naturally occurring in plants that have estrogenic/antiestrogenic effects. Phytoestrogens can modulate and be metabolized by the gut microbiota [123]. Phytoestrogen activity is strongly dependent on the microbiome. Their metabolites have stronger estrogenic activity than the natural compounds themselves, and because of the variability in microbiomes, there are large differences in the effects of phytoestrogens among individuals [124,125].

Daidzen, a phytoestrogen present in soy-based foods, can be metabolized to O-desmethylangolensin (ODMA) and equol by gut microbial communities in $80-95 \%$ and $25-60 \%$ of the population, respectively. In relation to this, Frankenfeld et al. $(2011,2014)[126,127]$ evaluated the presence of ODMA- and equol-metabolizing phenotypes in obese, overweight, and normal-weight individuals and found that the ODMA-metabolizing phenotype, but not the equol-phenotype, was linked to obesity in adulthood.

Another study investigated the effects of $S$-equol on pancreatic $\beta$-cell growth and insulin secretion in male mice. The results showed that $S$-equol boosts $\beta$-cell function and prevents hypoglycemia in mice, suggesting that $S$-equol may act as a potential preventive agent against type 2 diabetes mellitus [57]. Zhou et al. (2018) [64] investigated whether genistein intake by C57BL/6 female mice can reduce the negative impact of a maternal fat-high diet on glucose and lipid metabolism in their offspring. Female mice were placed on a high-fat diet alone, a high-fat diet supplemented with genistein at low $(0.25 \mathrm{~g} / \mathrm{kg}$ diet $)$ and high doses $n(0.6 \mathrm{~g} / \mathrm{kg}$ diet $)$, or a genistein-free control diet, for three weeks prior to pregnancy and throughout gestation and lactation. After weaning, female offspring from the high-fat group had lower weight at birth, as well as glucose intolerance and higher insulin, triacylglycerol, and total cholesterol levels in the serum compared with the control group. Offspring from the low-dose genistein group showed an increased weight at birth, improved glucose tolerance, and decreased fasting insulin. Offspring from the high-dose genistein group showed decreased serum triacylglycerols and total cholesterol compared with the offspring from the low-dose genistein mothers. The high abundances of Bacteroides and Akkermansia in the offspring from the genistein-fed female parents might be key to the improvement of glucose metabolism. A decrease of Bacteroides has been shown in diabetes patients in comparison to in healthy controls [128]. In addition, it has been reported that Akkermansia could preserve the mucus layer thickness and is correlated with an improved metabolic profile [129]. Similarly, the increased Rikenella in the offspring from the high genistein group might be linked to the decreased triacylglycerols and total cholesterol in the serum. In addition, it has been reported that the abundance of Rikinella contributes to a lean body type phenotype [130].

Lopez et al. (2018) [59] also found, in nine-week-old male C57/BL6 mice, lower serum triglycerides, improved glucose metabolism, and lower weights in the high-fat diet and genistein group ( $3 \mathrm{mg} / \mathrm{kg} /$ day) compared to in mice fed the high-fat diet alone. In addition, the presence of genistein in the high-fat 
diet resulted in changes to the gut microbiota (increases in the Prevotella and Akkermansia genera), linked to lower circulating levels of lipopolysaccharides and the reduced expression of pro-inflammatory cytokines in the liver, compared to in mice in the high-fat diet alone group. It has been showed that the reduction of lipopolysaccharides can decrease neuroinflammation [131].

Recently, Huang et al. (2018) [58] investigated, in non-obese diabetic mice, perinatally exposed to physiological doses of genistein $(20 \mathrm{mg} / \mathrm{kg}$ body weight), whether there is a sex-dependent effect on type 1 diabetes (T1D). In female offspring, perinatal exposure to genistein resulted in a higher incidence of early-onset T1D. In addition, increased Enterobacterials were found in the fecal microbiota from the PND90 female offspring, which is indicative of a pro-inflammatory response. These changes were not found in the PND30 females. However, perinatal genistein exposure in PND90 males induced changes in the gut microbiota linked to an anti-inflammatory response. The authors conclude that a strong sex-specific effect was found in the perinatal genistein exposure window and that the mechanism of T1D in non-obese diabetic females is induced by immune system modulation of the gut microbiota. These results must be taken into account, since soy milk formula consumption during infancy was related to type 1 diabetes [132].

In California mice (Peromyscus californicus), Marshall et al. (2019) [60] also determined whether perinatal exposure to genistein $(250 \mathrm{mg} / \mathrm{kg}$ feed weight) promoted dysbiosis and altered gut metabolites. Female mothers were fed a diet with genistein or a genistein-free control diet. Their results showed that exposure to genistein resulted in sex-related disturbances of the gut microbiota and metabolites in the offspring. Positive associations between the gut microbiome, metabolome, and disruption of social and vocalization behaviors (audible calls above $20 \mathrm{kHz}$ ) were also found in the offspring of exposed dams. When male offspring from genistein-supplemented dams were compared with genistein-free offspring, calls above $20 \mathrm{kHz}$ correlated with daidzein, $\alpha$-tocopherol, Flexispira spp., and Odoribacter spp. The effects secondary to genistein exposure may result from disturbances to neurobehavioral programming or from changes in the microbiota linked to changes in gut metabolites. These results suggest that the gut microbiome and its metabolites can induce a disruption in the offspring's neurobehavioral programming, known as the "microbiome gut-brain axis".

The effect of soy intake on microbiota composition and diversity has been studied in other animal models, such as porcine models [61,63] and the Southern white rhinoceros [62]. Yeruva et al. (2016) [63] determined the influence of diet on the development of the immune system in neonates, using a porcine model. Two-day old piglets were fed soy or milk formula until day 21 and compared to a sow-fed group, and the results showed that the formula diets induced changes in the small intestine microbiome, particularly in the duodenum. Significant increases in Lactobacillaceae spp. and Clostria spp., as well as a decrease in Enterobacteriaceae spp., were found in soy-fed piglets.

There is, however, little information regarding the impact of phytoestrogens on the human microbiota. Wu et al. (2016) [82] compared the plasma metabolites in omnivores versus vegans that consume soyfoods and found significant differences in the metabolomes between the two groups, but the gut microbiota was very similar in both groups [82].

\subsubsection{Metals}

Metals have been considered EDCs because of their ability to bind to hormone receptors [133]. Metals are ubiquitous environmental pollutants, with the primary sources of human exposure being the inhalation of dust or direct ingestion of contaminated food and water. Metal exposure has been related to obesity, diabetes, and metabolic syndrome [134-137].

Metals can be metabolized by the colonic microbiota in humans. Van de Wiele et al. (2010) [35] reported the ability of this microbiota to methylate Arsenic (As), which suggests that the role played by microbiota metabolism should be considered when assessing the toxic effects on human health of ingested As.

Lu et al. (2014) [45] reported that the composition of the gut microbiome in C57BL/6 mice markedly alters after exposure to $10 \mathrm{ppm}$ arsenic in the drinking water over 4 weeks, resulting in a decrease in 
four Firmicutes families. These results are in agreement with the As antiobesogenic properties described in several articles [138]. They also reported a significant association between this microbiota disruption and changes in microbiota metabolites. This suggests that exposure to As not only induces disturbances in the abundance and composition of bacterial communities but also affects their metabolomic profile, which subsequently results in the disturbance of host metabolite homeostasis. These changes in metabolite homeostasis are important risk factors involved in tissue dysfunctions, which may cause diseases such as obesity and diabetes [139].

$\mathrm{Wu}$ et al. (2016) [43] reported that perinatal lead $(\mathrm{Pb})$ exposure (32 ppm) in the drinking water, in wild-type non-agouti (a/a) mice of the Avy strain isogenic mouse model of perinatal environmental exposure, induced changes in the adult offspring gut microbiota. These changes were sex-independent, but a strong association was found between male offspring and increased body weight. Interestingly, the quantities of the two predominant phyla (Bacteroidetes and Firmicutes) shifted inversely with $\mathrm{Pb}$ exposure. In addition, reduced aerobic bacteria and increased anaerobic bacteria were observed in the exposed offspring. Lastly, Pseudomonas, Enterobacter, and Desulfovibrio were found in higher abundances in exposed adult mice than in controls $(p<0.05)$ [43].

Ba et al. (2017) [42] demonstrated the sex-specific effects of low-dose exposure to cadmium and found that early exposure to $100 \mathrm{nM}$ induced fat accumulation in adult male C57BL/6J mice. In this work, $100 \mathrm{nM}$ cadmium was present in the drinking water, which is equivalent to $\sim 2.5 \mu \mathrm{g} / \mathrm{kg}$ bw per week and corresponds to the tolerable weekly intake and the mean intake by humans [140]. They also found an increased metabolism of fatty acids and lipids as well as a decrease in the composition and diversity of the gut microbiota. At eight weeks, the gut microbiota was found to be particularly vulnerable to low-dose cadmium exposure, and exposure during this period may induce adiposity in adult mice, even if the microbiota is later restored. The role played by the gut microbiota in adiposity related to cadmium exposure was also demonstrated by microbiota transplantation and removal experiments.

Xia et al. (2018) [44] observed that short-term exposure to 10 and $30 \mu \mathrm{g} / \mathrm{L} \mathrm{Pb}$ increased the volume of intestinal mucus in the adult male zebrafish. They also found decreased $\alpha$-Proteobacteria and increased Firmicutes after exposure to $30 \mu \mathrm{g} / \mathrm{L} \mathrm{Pb}$ for seven days. In addition, 16S rRNA sequencing demonstrated an altered gut microbiota, in terms of composition and diversity, after exposure to $30 \mu \mathrm{g} / \mathrm{L} \mathrm{Pb}$. At this dose, 52 gut microbes and 41 metabolites underwent significant changes, particularly those related to the pathways of glucose, lipid, amino acid, and nucleotide metabolism. Lastly, they also found a marked reduction in the transcription of some genes related to glycolysis and lipid metabolism after seven-day exposure to $30 \mu \mathrm{g} / \mathrm{L} \mathrm{Pb}$.

A recent study showed that the urinary concentrations of $\mathrm{Pb}$ in adult humans were related to changes in gut microbial composition, even at low $\mathrm{Pb}$ levels [81], and so an association between increased urinary $\mathrm{Pb}$ concentrations and increased microbiota $\alpha$-diversity and richness was found. Changes in $\beta$-diversity were significantly associated with changes in urinary $\mathrm{Pb}$ concentrations, and Proteobacteria, including members of the Burkholderiales (a wide variety of bacterial species that perform a plethora of metabolic functions), were also associated with increased urinary $\mathrm{Pb}$ [81].

\subsubsection{Triclosan and Triclocarban}

Triclosan (TCS) and triclocarban (TCC) (TCs) are chlorinated, broad-spectrum antimicrobial endocrine disrupting chemicals found in thousands of consumer and industrial products [141], as well as in contaminated food [142,143]. These EDCs have been related to metabolic disorders such as obesity and diabetes [144,145].

It has been shown that TCS exposure induces changes in the gut microbiota of rats [66,77], mice [75], and fish [76,79]. Narrowe et al. (2015) [79] showed that even low but environmentally relevant levels of triclosan exposure (100-1000 ng/mL) can result in the disturbance of the juvenile fish gut microbiome. Seven-day exposure to triclosan in larval fathead minnows (P. promelas) resulted in significant changes, as measured by $\alpha$ - and $\beta$-diversity, in the gut microbiome immediately after triclosan exposure; 
however, the microbiome rapidly recovered following two weeks of depuration. This demonstrates the sensitivity and resilience of the gut flora to the toxic effects of environmental contaminants.

Kennedy et al. (2016) [77] found that Sprague Dawley rats with ad libitum access to commercial Harlan ground 2020X supplemented with $0.1 \%$ w/w triclocarban during gestation and lactation exhibited significant changes in the community structure of the fecal microbiota, as well as finding decreased phylogenetic diversity in exposed dams and neonatal rats. Marked differences in $\beta$-diversity were found in exposed animals compared with controls in dams at 18 days of gestation and 16 day old neonates. This dose was chosen as it has been demonstrated that the serum TCC concentration of pregnant rats after oral exposure to $0.2 \% w / w$ TCC was similar to the concentrations reported in the human serum [146].

Ma et al. (2020) [78] studied the long-term effects in adult and old rats of perinatal exposure to TCs and found that $50 \mathrm{mg} / \mathrm{kg} /$ day (the lowest toxic oral dose in rats) resulted in disturbances of the metabolism and gut microbiota that were long-lasting and persisted even after the exposure had been terminated. They also accumulated over time, inducing metabolic disorders in old rat offspring. Exposure to TCs induced an increased growth of Bacteroidetes, which has been related to lipid accumulation [42]. Additionally, a reduction in Akkermansia muciniphila, a species linked to improved metabolism in diabetic and obese mice, was observed [147].

Interestingly, probiotics have been used to modulate the microbiota and palliate intestinal metabolic disorders due to triclosan exposure in animal models [80]. In this respect, Lactobacillus plantarum ST-III has been found to increase the diversity of the gut microbiota in zebrafish, thereby reducing the toxicity of chronic exposure to triclosan. Additionally, a probiotic-rich diet reduced the risk of lipid-metabolism disorders such as increased triglyceride and total cholesterol levels. Histopathological studies demonstrated severe structural damage to the intestines, spleen, and kidney after triclosan exposure; however, this damage can be reduced by the presence of Lactobacillus.

Bever et al. (2018) [85] compared the fecal microbiome of infants fed with breast milk that had measurable levels of TCS versus infants fed with breast milk that had no detectable concentrations of TCS and found that early life exposure to exogenous contaminants induces changes to microbiome diversity. Because of the impact of a healthy infant gut microbiome on phenotypes later in life, understanding how EDCs influence the infant gut microbiome is critical to identifying and correcting problematic changes in infant gut health.

However, Ribado et al. (2017) [86] did not find that exposure to household TC-containing products induces changes to or a loss of microbial diversity, but they found increased Proteobacteria spp. in infants and mothers exposed to higher TC levels. Interestingly, increased Proteobacteria has been proposed as a potential diagnostic marker for dysbiosis and an increased risk of diabetes and colitis [148].

\subsubsection{Phthalates}

Phthalates are EDCs used as plasticizers in food processing and packaging, adhesives, personal care products, and cosmetics. A major source of phthalate exposure is the diet, primarily due to contamination during processing and packaging [149]. Phthalates have been considered obesogens, therefore contributing to overweightness and obesity. It has been shown that exposure to phthalates alters glucose and lipid metabolism, which increases the risk of developing insulin resistance $[150,151]$.

A mouse model of prenatal di(2-etilhexil) ftalato (DEHP) exposure $(0.2,2$, and $20 \mathrm{mg} / \mathrm{kg} /$ day) was used to study the long-term metabolic disturbances in offspring. In an ICR mouse model of prenatal DEHP exposure (0.2, 2, and $20 \mathrm{mg} / \mathrm{kg} /$ day), Fan et al. (2020) [67] showed that exposure to low-dose phthalate $(0.2 \mathrm{mg} / \mathrm{kg} /$ day $)$ in mice induced changes in glucose metabolism, energy expenditure, adipogenesis, and gut dysbiosis in a sex-dependent manner. The level of DEHP exposure was selected based on the EPA reference dose. Their findings strengthen the hypothesis that connections between the host and gut microbiota alter energy metabolism.

As mentioned above, Hu et al. (2016) [66] reported that postnatal, low-dose exposure to diethyl phthalate (DEP) in Sprague-Dawley rats from birth through adulthood induced changes in 
the composition of the gut microbiota, but these changes were seen only in adolescent rats. The changes include an increased relative abundance of Bacteroidetes (Prevotella) Elusimicrobia and decreased Firmicutes (Bacilli) in exposed rats versus controls. Surprisingly, these DEP-induced changes decreased in adulthood despite continuous exposure, which suggests that the effects of exposure to environmental chemicals are more severe in adolescents. They also observed a small but consistent reduction of body weight in exposed adolescent rats, which is consistent with their findings of a reduced Firmicutes/Bacteroidetes ratio.

Lei et al. (2019) [37] conducted in vivo and in vitro experiments in female C57BL/6J mice to determine the effects of low or high dose DEHP (1 or $10 \mathrm{mg} / \mathrm{kg} \mathrm{bw} /$ day) exposure on the gut microbiota composition and metabolite profile. The authors observed an increased abundance of Lachnoclostridium and decreased Clostridium sensu stricto after DEHP exposure. The addition of DEHP to the cultured cecal microbiota enhanced the abundance of Lachnoclostridium, which is able to produce p-hydroxyphenylacetic acid, the precursor of p-cresol, a bacterial metabolite linked to neurodevelopmental disorders.

Regarding human epidemiological studies, the information is scarce. Yang et al. (2019) [83] demonstrated in a recent epidemiological study showing that DEHP exposure in newborns resulted in changes to the microbiota composition, with a decrease in Rothia sp. and Bifidobacterium longum. The presence of Rothia in human milk has been associated with a minor incidence of asthma [152], and $B$. longum, considered a probiotic, seems to have positive effects on infants, particularly in reducing the risk of obesity and celiac disease.

\section{Conclusions}

The incidence of metabolic diseases such as obesity and T2D are increasing worldwide. Exposure to EDCs related to food intake induces a series of changes including microbial dysbiosis and the induction of xenobiotic pathways and associated genes, enzymes, and metabolites involved in EDC metabolism. The products and by-products released following the microbial metabolism of EDCs can be taken up by the host and could have a major impact on host metabolism and the development of metabolic diseases. However, data regarding the effects of EDCs on the human gut microbiota are limited. The increasing EDC exposure via dietary intake requires the identification of the compounds and of the specific responses of the different species of the gut microbiome. In addition, the characterization of the common mechanisms of action of the different EDCs—such as the binding of the same hormone receptors, their possible cumulative and combined effects, and the indicative bacteria underlying the toxicity of EDCs on the gut microbiota-is also essential. In addition, the effect of exposure to low EDC levels on microbiota disruption should also be considered. The impact of other parameters such as host age and sex on the gut microbiota, described in this review, make necessary further research with broader dose ranges and analyses with more time points. This will help to determine the origin of sex-dependent effects using additional exposure windows. Lastly, the remediation of EDC-induced changes in the gut microbioma might represent an alternative for the treatment and prevention of metabolic diseases.

Author Contributions: Conceptualization, A.R.; methodology, A.R., C.M., Y.G.-O. and S.P.; writing-original draft preparation, Y.G.-O., S.P., C.M. and A.R review and editing, Y.G.-O., C.M. and A.R. All authors have read and agreed to the published version of the manuscript.

Funding: This work was carried out within the frame of GP/EFSA/ENCO/380 2018/03/G04: OBEMIRISK: Knowledge platform for assessing the risk of Bisphenols on gut microbiota and its role in obesogenic phenotype: looking for biomarkers. This research was also funded by Plan Estatal de I+D+I 2013-2016, Proyecto cofinanciado FEDER-ISCIII PI17/01758, Proyecto cofinanciado FEDER-Consejería de Salud y Familias, Junta de Andalucía PE-0250-2019 and by Fundación Mapfre MAPFRE2018.

Acknowledgments: The results presented in this article constitute part of Yolanda Gálvez-Ontiveros doctoral thesis, performed in the Nutrition and Food Sciences Doctorate Program of the University of Granada.

Conflicts of Interest: The authors declare no conflict of interest. 


\section{References}

1. Zoeller, R.T.; Brown, T.R.; Doan, L.L.; Gore, A.C.; Skakkebaek, N.E.; Soto, A.M.; Woodruff, T.J.; Saal, F.S.V. Endocrine-Disrupting Chemicals and Public Health Protection: A Statement of Principles from the Endocrine Society. Endocrinology 2012, 153, 4097-4110. [CrossRef]

2. Gore, A.C.; Chappell, V.A.; Fenton, S.E.; Flaws, J.A.; Nadal, A.; Prins, G.S.; Toppari, J.; Zoeller, R.T. EDC-2: The Endocrine Society's Second Scientific Statement on Endocrine-Disrupting Chemicals. Endocr. Rev. 2015, 36, E1-E150. [CrossRef]

3. Mantovani, A. Endocrine Disrupters and the Safety of Food Chains. Horm. Res. Paediatr. 2016, 86, $279-288$. [CrossRef]

4. Heindel, J.J.; Blumberg, B.; Cave, M.; Machtinger, R.; Mantovani, A.; Mendez, M.A.; Nadal, A.; Palanza, P.; Panzica, G.; Sargis, R.; et al. Metabolism Disrupting Chemicals and Metabolic Disorders. Reprod. Toxicol. 2017, 68, 3-33. [CrossRef]

5. Malaise, Y.; Menard, S.; Cartier, C.; Gaultier, E.; Lasserre, F.; Lencina, C.; Harkae, C.; Geoffre, N.; Lakhal, L.; Castan, I.; et al. Gut Dysbiosis and Impairment of Immune System Homeostasis in Perinatally-Exposed Mice to Bisphenol A Precede Obese Phenotype Development. Sci. Rep. 2017, 7, 14472. [CrossRef] [PubMed]

6. Xu, J.; Huang, G.; Nagy, T.; Guo, T.L. Bisphenol A Alteration of Type 1 Diabetes in Non-Obese Diabetic (NOD) Female Mice is Dependent on Window of Exposure. Arch. Toxicol. 2019, 93, 1083-1093. [CrossRef] [PubMed]

7. Rosenfeld, C.S. Gut Dysbiosis in Animals due to Environmental Chemical Exposures. Front. Cell. Infect. Microbiol. 2017, 7, 396. [CrossRef] [PubMed]

8. Velmurugan, G.; Ramprasath, T.; Gilles, M.; Swaminathan, K.; Ramasamy, S. Gut Microbiota, Endocrine-Disrupting Chemicals, and the Diabetes Epidemic. Trends Endocrinol. Metab. 2017, 28, 612-625. [CrossRef]

9. Claus, S.P.; Guillou, H.; Ellero-Simatos, S. The Gut Microbiota: A Major Player in the Toxicity of Environmental Pollutants? NPJ Biofilms Microbiomes 2016, 2, 16003. [CrossRef]

10. Moher, D.; Liberati, A.; Tetzlaff, J.; Altman, D.G.; PRISMA Group. Preferred Reporting Items for Systematic Reviews and Meta-Analyses: The PRISMA Statement. J. Clin. Epidemiol. 2009, 62, 1006-1012. [CrossRef]

11. Wang, B.; Yao, M.; Lv, L.; Ling, Z.; Li, L. The Human Microbiota in Health and Disease. Engineering 2017, 3, 71-82. [CrossRef]

12. Arumugam, M.; Raes, J.; Pelletier, E.; Le Paslier, D.; Yamada, T.; Mende, D.R.; Fernandes, G.R.; Tap, J.; Bruls, T.; Batto, J.; et al. Enterotypes of the Human Gut Microbiome. Nature 2011, 473, 174-180. [CrossRef] [PubMed]

13. Rinninella, E.; Raoul, P.; Cintoni, M.; Franceschi, F.; Miggiano, G.A.D.; Gasbarrini, A.; Mele, M.C. What is the Healthy Gut Microbiota Composition? A Changing Ecosystem across Age, Environment, Diet, and Diseases. Microorganisms 2019, 7, 14. [CrossRef] [PubMed]

14. Erejuwa, O.O.; Sulaiman, S.A.; Ab Wahab, M.S. Modulation of Gut Microbiota in the Management of Metabolic Disorders: The Prospects and Challenges. Int. J. Mol. Sci. 2014, 15, 4158-4188. [CrossRef]

15. Ley, R.E.; Backhed, F.; Turnbaugh, P.; Lozupone, C.A.; Knight, R.D.; Gordon, J.I. Obesity Alters Gut Microbial Ecology. Proc. Natl. Acad. Sci. USA 2005, 102, 11070-11075. [CrossRef]

16. Orlando Mendez-Salazar, E.; Guadalupe Ortiz-Lopez, M.; de los Angeles Granados-Silvestre, M.; Palacios-Gonzalez, B.; Menjivar, M. Altered Gut Microbiota and Compositional Changes in Firmicutes and Proteobacteria in Mexican Undernourished and Obese Children. Front. Microbiol. 2018, 9, 2494. [CrossRef]

17. Gallardo-Becerra, L.; Cornejo-Granados, F.; Garcia-Lopez, R.; Valdez-Lara, A.; Bikel, S.; Canizales-Quinteros, S.; Lopez-Contreras, B.E.; Mendoza-Vargas, A.; Nielsen, H.; Ochoa-Leyva, A. Metatranscriptomic Analysis to Define the Secrebiome, and 16S rRNA Profiling of the Gut Microbiome in Obesity and Metabolic Syndrome of Mexican Children. Microb. Cell Factories 2020, 19, 61. [CrossRef]

18. Bervoets, L.; Van Hoorenbeeck, K.; Kortleven, I.; Van Noten, C.; Hens, N.; Vael, C.; Goossens, H.; Desager, K.N.; Vankerckhoven, V. Differences in Gut Microbiota Composition between Obese and Lean Children: A Cross-Sectional Study. Gut Pathog. 2013, 5, 10. [CrossRef]

19. Rizzatti, G.; Lopetuso, L.R.; Gibiino, G.; Binda, C.; Gasbarrini, A. Proteobacteria: A Common Factor in Human Diseases. BioMed Res. Int. 2017, 2017, 9351507. [CrossRef] 
20. Geurts, L.; Lazarevic, V.; Derrien, M.; Everard, A.; Van Roye, M.; Knauf, C.; Valet, P.; Girard, M.; Muccioli, G.G.; Francois, P.; et al. Altered Gut Microbiota and Endocannabinoid System Tone in Obese and Diabetic Leptin-Resistant Mice: Impact on Apelin Regulation in Adipose Tissue. Front. Microbiol. 2011, 2, 149. [CrossRef]

21. Cani, P.D. Gut Microbiota and Obesity: Lessons from the Microbiome. Brief. Funct. Genom. 2013, 12, 381-387. [CrossRef]

22. Zhang, C.; Zhang, M.; Wang, S.; Han, R.; Cao, Y.; Hua, W.; Mao, Y.; Zhang, X.; Pang, X.; Wei, C.; et al. Interactions between Gut Microbiota, Host Genetics and Diet Relevant to Development of Metabolic Syndromes in Mice. ISME J. 2010, 4, 232-241. [CrossRef] [PubMed]

23. Larsen, N.; Vogensen, F.K.; van den Berg, F.W.J.; Nielsen, D.S.; Andreasen, A.S.; Pedersen, B.K.; Abu Al-Soud, W.; Sorensen, S.J.; Hansen, L.H.; Jakobsen, M. Gut Microbiota in Human Adults with Type 2 Diabetes Differs from Non-Diabetic Adults. PLoS ONE 2010, 5, e9085. [CrossRef] [PubMed]

24. Murri, M.; Leiva, I.; Miguel Gomez-Zumaquero, J.; Tinahones, F.J.; Cardona, F.; Soriguer, F.; Isabel Queipo-Ortuno, M. Gut Microbiota in Children with Type 1 Diabetes Differs from that in Healthy Children: A Case-Control Study. BMC Med. 2013, 11, 46. [CrossRef] [PubMed]

25. Apau, J.; Acheampong, A.; Adua, E. Exposure to Bisphenol A, Bisphenol F, and Bisphenol S can Result in Obesity in Human Body. Cogent Chem. 2018, 4, 1506601. [CrossRef]

26. García, S. Estudio de la Migración de Distintos Componentes de los Materiales Plásticos a los Alimentos. Ph.D. Thesis, University of Santiago de Compostela, Santiago de Compostela, Spain, 2005.

27. Verbanck, M.; Canouil, M.; Leloire, A.; Dhennin, V.; Coumoul, X.; Yengo, L.; Froguel, P.; Poulain-Godefroy, O. Low-Dose Exposure to Bisphenols A, F and S of Human Primary Adipocyte Impacts Coding and Non-Coding RNA Profiles. PLoS ONE 2017, 12, e0179583. [CrossRef]

28. Wang, Y.; Rui, M.; Nie, Y.; Lu, G. Influence of Gastrointestinal Tract on Metabolism of Bisphenol A as Determined by in Vitro Simulated System. J. Hazard. Mater. 2018, 355, 111-118. [CrossRef]

29. Catron, T.R.; Keely, S.P.; Brinkman, N.E.; Zurlinden, T.J.; Section, C.E.W.; Wright, J.R.; Phelps, D.; Wheaton, E.; Kvasnicka, A.; Gaballah, S.; et al. Host Developmental Toxicity of BPA and BPA Alternatives is Inversely Related to Microbiota Disruption in Zebrafish. Toxicol. Sci. 2019, 167, 468-483. [CrossRef]

30. Chen, L.; Guo, Y.; Hu, C.; Lam, P.K.S.; Lam, J.C.W.; Zhou, B. Dysbiosis of Gut Microbiota by Chronic Coexposure to Titanium Dioxide Nanoparticles and Bisphenol A: Implications for Host Health in Zebrafish. Environ. Pollut. 2018, 234, 307-317. [CrossRef]

31. Javurek, A.B.; Spollen, W.G.; Johnson, S.A.; Bivens, N.J.; Bromert, K.H.; Givan, S.A.; Rosenfeld, C.S. Effects of Exposure to Bisphenol A and Ethinyl Estradiol on the Gut Microbiota of Parents and their Offspring in a Rodent Model. Gut Microbes 2016, 7, 471-485. [CrossRef]

32. Liu, Y.; Yao, Y.; Li, H.; Qiao, F.; Wu, J.; Du, Z.; Zhang, M. Influence of Endogenous and Exogenous Estrogenic Endocrine on Intestinal Microbiota in Zebrafish. PLoS ONE 2016, 11, e0163895. [CrossRef] [PubMed]

33. Xu, J.; Huang, G.; Nagy, T.; Teng, Q.; Guo, T.L. Sex-Dependent Effects of Bisphenol A on Type 1 Diabetes Development in Non-Obese Diabetic (NOD) Mice. Arch. Toxicol. 2019, 93, 997-1008. [CrossRef] [PubMed]

34. Calafat, A.M.; Kuklenyik, Z.; Reidy, J.A.; Caudill, S.P.; Ekong, J.; Needham, L.L. Urinary Concentrations of Bisphenol A and 4-Nonylphenol in a Human Reference Population. Environ. Health Perspect. 2005, 113, 391-395. [CrossRef] [PubMed]

35. Van de Wiele, T.; Gallawa, C.M.; Kubachka, K.M.; Creed, J.T.; Basta, N.; Dayton, E.A.; Whitacre, S.; Du Laing, G.; Bradham, K. Arsenic Metabolism by Human Gut Microbiota upon in Vitro Digestion of Contaminated Soils. Environ. Health Perspect. 2010, 118, 1004-1009. [CrossRef] [PubMed]

36. Hoffman, J.B.; Flythe, M.D.; Hennig, B. Environmental Pollutant-Mediated Disruption of Gut Microbial Metabolism of the Prebiotic Inulin. Anaerobe 2019, 55, 96-102. [CrossRef] [PubMed]

37. Lei, M.; Menon, R.; Manteiga, S.; Alden, N.; Hunt, C.; Alaniz, R.C.; Lee, K.; Jayaraman, A. Environmental Chemical Diethylhexyl Phthalate Alters Intestinal Microbiota Community Structure and Metabolite Profile in Mice. mSystems 2019, 4. [CrossRef]

38. Joly, C.; Gay-Queheillard, J.; Leke, A.; Chardon, K.; Delanaud, S.; Bach, V.; Khorsi-Cauet, H. Impact of Chronic Exposure to Low Doses of Chlorpyrifos on the Intestinal Microbiota in the Simulator of the Human Intestinal Microbial Ecosystem (SHIME (R)) and in the Rat. Environ. Sci. Pollut. Res. 2013, 20, 2726-2734. [CrossRef] 
39. Shehata, A.A.; Schroedl, W.; Aldin, A.A.; Hafez, H.M.; Krueger, M. The Effect of Glyphosate on Potential Pathogens and Beneficial Members of Poultry Microbiota in Vitro. Curr. Microbiol. 2013, 66, 350-358. [CrossRef]

40. Ackermann, W.; Coenen, M.; Schroedl, W.; Shehata, A.A.; Krueger, M. The Influence of Glyphosate on the Microbiota and Production of Botulinum Neurotoxin during Ruminal Fermentation. Curr. Microbiol. 2015, 70, 374-382. [CrossRef]

41. Riede, S.; Toboldt, A.; Breves, G.; Metzner, M.; Koehler, B.; Braeunig, J.; Schafft, H.; Lahrssen-Wiederholt, M.; Niemann, L. Investigations on the Possible Impact of a Glyphosate-Containing Herbicide on Ruminal Metabolism and Bacteria Invitro by Means of the 'Rumen Simulation Technique'. J. Appl. Microbiol. 2016, 121, 644-656. [CrossRef]

42. Ba, Q.; Li, M.; Chen, P.; Huang, C.; Duan, X.; Lu, L.; Li, J.; Chu, R.; Xie, D.; Song, H.; et al. Sex-Dependent Effects of Cadmium Exposure in Early Life on Gut Microbiota and Fat Accumulation in Mice. Environ. Health Perspect. 2017, 125, 437-446. [CrossRef]

43. Wu, J.; Wen, X.W.; Faulk, C.; Boehnke, K.; Zhang, H.; Dolinoy, D.C.; Xi, C. Perinatal Lead Exposure Alters Gut Microbiota Composition and Results in Sex-Specific Bodyweight Increases in Adult Mice. Toxicol. Sci. 2016, 151, 324-333. [CrossRef] [PubMed]

44. Xia, J.; Lu, L.; Jin, C.; Wang, S.; Zhou, J.; Ni, Y.; Fu, Z.; Jin, Y. Effects of Short Term Lead Exposure on Gut Microbiota and Hepatic Metabolism in Adult Zebrafish. Comp. Biochem. Physiol. C-Toxicol. Pharmacol. 2018, 209, 1-8. [CrossRef] [PubMed]

45. Lu, K.; Abo, R.P.; Schlieper, K.A.; Graffam, M.E.; Levine, S.; Wishnok, J.S.; Swenberg, J.A.; Tannenbaum, S.R.; Fox, J.G. Arsenic Exposure Perturbs the Gut Microbiome and its Metabolic Profile in Mice: An Integrated Metagenomics and Metabolomics Analysis. Environ. Health Perspect. 2014, 122, 284-291. [CrossRef] [PubMed]

46. DeLuca, J.A.A.; Allred, K.F.; Menon, R.; Riordan, R.; Weeks, B.R.; Jayaraman, A.; Allred, C.D. Bisphenol-A Alters Microbiota Metabolites Derived from Aromatic Amino Acids and Worsens Disease Activity during Colitis. Exp. Biol. Med. 2018, 243, 864-875. [CrossRef] [PubMed]

47. Koestel, Z.L.; Backus, R.C.; Tsuruta, K.; Spollen, W.G.; Johnson, S.A.; Javurek, A.B.; Ellersieck, M.R.; Wiedmeyer, C.E.; Kannan, K.; Xue, J.; et al. Bisphenol A (BPA) in the Serum of Pet Dogs Following Short-Term Consumption of Canned Dog Food and Potential Health Consequences of Exposure to BPA. Sci. Total Environ. 2017, 579, 1804-1814. [CrossRef]

48. Lai, K.; Chung, Y.; Li, R.; Wan, H.; Wong, C.K. Bisphenol A Alters Gut Microbiome: Comparative Metagenomics Analysis. Environ. Pollut. 2016, 218, 923-930. [CrossRef]

49. Reddivari, L.; Veeramachaneni, D.N.R.; Walters, W.A.; Lozupone, C.; Palmer, J.; Hewage, M.K.K.; Bhatnagar, R.; Amir, A.; Kennett, M.J.; Knight, R.; et al. Perinatal Bisphenol A Exposure Induces Chronic Inflammation in Rabbit Offspring via Modulation of Gut Bacteria and their Metabolites. mSystems 2017, 2, e00093-17. [CrossRef]

50. Chen, L.; Zhang, W.; Hua, J.; Hu, C.; Lai, N.L.; Jan, P.; Lam, P.K.S.; Lam, J.C.W.; Zhou, B. Dysregulation of Intestinal Health by Environmental Pollutants: Involvement of the Estrogen Receptor and Aryl Hydrocarbon Receptor. Environ. Sci. Technol. 2018, 52, 2323-2330. [CrossRef]

51. Cheng, S.L.; Li, X.; Lehmler, H.; Phillips, B.; Shen, D.; Cui, J.Y. Gut Microbiota Modulates Interactions between Polychlorinated Biphenyls and Bile Acid Homeostasis. Toxicol. Sci. 2018, 166, 269-287. [CrossRef]

52. Chi, Y.; Lin, Y.; Lu, Y.; Huang, Q.; Ye, G.; Dong, S. Gut Microbiota Dysbiosis Correlates with a Low-Dose PCB126-Induced Dyslipidemia and Non-Alcoholic Fatty Liver Disease. Sci. Total Environ. 2019, 653, $274-282$. [CrossRef] [PubMed]

53. Choi, J.J.; Eum, S.Y.; Rampersaud, E.; Daunert, S.; Abreu, M.T.; Toborek, M. Exercise Attenuates PCB-Induced Changes in the Mouse Gut Microbiome. Environ. Health Perspect. 2013, 121, 725-730. [CrossRef] [PubMed]

54. Kohl, K.D.; Cary, T.L.; Karasov, W.H.; Dearing, M.D. Larval Exposure to Polychlorinated Biphenyl 126 (Pcb-126) Causes Persistent Alteration of the Amphibian Gut Microbiota. Environ. Toxicol. Chem. 2015, 34, 1113-1118. [CrossRef] [PubMed]

55. Petriello, M.C.; Hoffman, J.B.; Vsevolozhskaya, O.; Morris, A.J.; Hennig, B. Dioxin-Like PCB 126 Increases Intestinal Inflammation and Disrupts Gut Microbiota and Metabolic Homeostasis. Environ. Pollut. 2018, 242, 1022-1032. [CrossRef] [PubMed] 
56. Rude, K.M.; Pusceddu, M.M.; Keogh, C.E.; Sladek, J.A.; Rabasa, G.; Miller, E.N.; Sethi, S.; Keil, K.P.; Pessah, I.N.; Lein, P.J.; et al. Developmental Exposure to Polychlorinated Biphenyls (PCBs) in the Maternal Diet Causes Host-Microbe Defects in Weanling Offspring Mice. Environ. Pollut. 2019, 253, 708-721. [CrossRef] [PubMed]

57. Horiuchi, H.; Usami, A.; Shirai, R.; Harada, N.; Ikushiro, S.; Sakaki, T.; Nakano, Y.; Inui, H.; Yamaji, R. $\mathrm{S}$-Equol Activates cAMP Signaling at the Plasma Membrane of INS-1 Pancreatic B-Cells and Protects against Streptozotocin-Induced Hyperglycemia by Increasing B-Cell Function in Male Mice. J. Nutr. 2017, 147, 1631-1639. [CrossRef] [PubMed]

58. Huang, G.; Xu, J.; Cai, D.; Chen, S.; Nagy, T.; Guo, T.L. Exacerbation of Type 1 Diabetes in Perinatally Genistein Exposed Female Non-Obese Diabetic (NOD) Mouse is Associated with Alterations of Gut Microbiota and Immune Homeostasis. Toxicol. Sci. 2018, 165, 291-301. [CrossRef]

59. Lopez, P.; Sanchez, M.; Perez-Cruz, C.; Velazquez-Villegas, L.A.; Syeda, T.; Aguilar-Lopez, M.; Rocha-Viggiano, A.K.; del Carmen Silva-Lucero, M.; Torre-Villalvazo, I.; Noriega, L.G.; et al. Long-Term Genistein Consumption Modifies Gut Microbiota, Improving Glucose Metabolism, Metabolic Endotoxemia, and Cognitive Function in Mice Fed a High-Fat Diet. Mol. Nutr. Food Res. 2018, 62, 1800313. [CrossRef]

60. Marshall, B.L.; Liu, Y.; Farrington, M.J.; Mao, J.; Helferich, W.G.; Schenk, A.K.; Bivens, N.J.; Sarma, S.J.; Lei, Z.; Sumner, L.W.; et al. Early Genistein Exposure of California Mice and Effects on the Gut Microbiota Brain Axis. J. Endocrinol. 2019, 242, 139-157. [CrossRef]

61. Piccolo, B.D.; Mercer, K.E.; Bhattacharyya, S.; Bowlin, A.K.; Saraf, M.K.; Pack, L.; Chintapalli, S.V.; Shankar, K.; Adams, S.H.; Badger, T.M.; et al. Early Postnatal Diets Affect the Bioregional Small Intestine Microbiome and Ileal Metabolome in Neonatal Pigs. J. Nutr. 2017, 147, 1499-1509. [CrossRef]

62. Williams, C.L.; Ybarra, A.R.; Meredith, A.N.; Durrant, B.S.; Tubbs, C.W. Gut Microbiota and Phytoestrogen-Associated Infertility in Southern White Rhinoceros. Mbio 2019, 10, 311. [CrossRef] [PubMed]

63. Yeruva, L.; Spencer, N.E.; Saraf, M.K.; Hennings, L.; Bowlin, A.K.; Cleves, M.A.; Mercer, K.; Chintapalli, S.V.; Shankar, K.; Rank, R.G.; et al. Formula Diet Alters Small Intestine Morphology, Microbial Abundance and Reduces VE-Cadherin and IL-10 Expression in Neonatal Porcine Model. BMC Gastroenterol. 2016, 16, 40.

64. Zhou, L.; Xiao, X.; Zhang, Q.; Zheng, J.; Li, M.; Yu, M.; Wang, X.; Deng, M.; Zhai, X.; Li, R. Improved Glucose and Lipid Metabolism in the Early Life of Female Offspring by Maternal Dietary Genistein is Associated with Alterations in the Gut Microbiota. Front. Endocrinol. 2018, 9, 516. [CrossRef] [PubMed]

65. Obadia, B.; Keebaugh, E.S.; Yamada, R.; Ludington, W.B.; Ja, W.W. Diet Influences Host-Microbiota Associations in Drosophila. Proc. Natl. Acad. Sci. USA 2018, 115, E4547-E4548. [CrossRef] [PubMed]

66. Hu, J.; Raikhel, V.; Gopalakrishnan, K.; Fernandez-Hernandez, H.; Lambertini, L.; Manservisi, F.; Falcioni, L.; Bua, L.; Belpoggi, F.; Teitelbaum, S.L.; et al. Effect of Postnatal Low-Dose Exposure to Environmental Chemicals on the Gut Microbiome in a Rodent Model. Microbiome 2016, 4, 26. [CrossRef]

67. Fan, Y.; Qin, Y.; Chen, M.; Li, X.; Wang, R.; Huang, Z.; Xu, Q.; Yu, M.; Zhang, Y.; Han, X.; et al. Prenatal Low-Dose DEHP Exposure Induces Metabolic Adaptation and Obesity: Role of Hepatic Thiamine Metabolism. J. Hazard. Mater. 2020, 385, 121534. [CrossRef]

68. Gao, B.; Bian, X.; Mahbub, R.; Lu, K. Sex-Specific Effects of Organophosphate Diazinon on the Gut Microbiome and its Metabolic Functions. Environ. Health Perspect. 2017, 125, 198-206. [CrossRef]

69. Jin, Y.; Zeng, Z.; Wu, Y.; Zhang, S.; Fu, Z. Oral Exposure of Mice to Carbendazim Induces Hepatic Lipid Metabolism Disorder and Gut Microbiota Dysbiosis. Toxicol. Sci. 2015, 147, 116-126. [CrossRef]

70. Liang, Y.; Zhan, J.; Liu, D.; Luo, M.; Han, J.; Liu, X.; Liu, C.; Cheng, Z.; Zhou, Z.; Wang, P. Organophosphorus Pesticide Chlorpyrifos Intake Promotes Obesity and Insulin Resistance through Impacting Gut and Gut Microbiota. Microbiome 2019, 7, 19. [CrossRef]

71. Liu, Q.; Shao, W.; Zhang, C.; Xu, C.; Wang, Q.; Liu, H.; Sun, H.; Jiang, Z.; Gu, A. Organochloride Pesticides Modulated Gut Microbiota and Influenced Bile Acid Metabolism in Mice. Environ. Pollut. 2017, 226, $268-276$. [CrossRef]

72. Tu, P.; Gao, B.; Chi, L.; Lai, Y.; Bian, X.; Ru, H.; Lu, K. Subchronic Low-Dose 2,4-D Exposure Changed Plasma Acylcarnitine Levels and Induced Gut Microbiome Perturbations in Mice. Sci. Rep. 2019, 9, 4363. [CrossRef] [PubMed]

73. Yang, F.; Li, J.; Pang, G.; Ren, F.; Fang, B. Effects of Diethyl Phosphate, a Non-Specific Metabolite of Organophosphorus Pesticides, on Serum Lipid, Hormones, Inflammation, and Gut Microbiota. Molecules 2019, 24, 2003. [CrossRef] [PubMed] 
74. Wu, S.; Jin, C.; Wang, Y.; Fu, Z.; Jin, Y. Exposure to the Fungicide Propamocarb Causes Gut Microbiota Dysbiosis and Metabolic Disorder in Mice. Environ. Pollut. 2018, 237, 775-783. [CrossRef] [PubMed]

75. Gao, B.; Tu, P.; Bian, X.; Chi, L.; Ru, H.; Lu, K. Profound Perturbation Induced by Triclosan Exposure in Mouse Gut Microbiome: A Less Resilient Microbial Community with Elevated Antibiotic and Metal Resistomes. BMC Pharmacol. Toxicol. 2017, 18, 46. [CrossRef]

76. Gaulke, C.A.; Barton, C.L.; Proffitt, S.; Tanguay, R.L.; Sharpton, T.J. Triclosan Exposure is Associated with Rapid Restructuring of the Microbiome in Adult Zebrafish. PLoS ONE 2016, 11, e0154632. [CrossRef]

77. Kennedy, R.C.; Fling, R.R.; Robeson, M.S.; Saxton, A.M.; Donnell, R.L.; Darcy, J.L.; Bemis, D.A.; Liu, J.; Zhao, L.; Chen, J. Temporal Development of Gut Microbiota in Triclocarban Exposed Pregnant and Neonatal Rats. Sci. Rep. 2016, 6, 33430. [CrossRef]

78. Ma, Y.; Guo, Y.; Ye, H.; Zhang, J.; Ke, Y. Perinatal Triclosan Exposure in the Rat Induces Long-Term Disturbances in Metabolism and Gut Microbiota in Adulthood and Old Age. Environ. Res. 2020, 182, 109004. [CrossRef]

79. Narrowe, A.B.; Albuthi-Lantz, M.; Smith, E.P.; Bower, K.J.; Roane, T.M.; Vajda, A.M.; Miller, C.S. Perturbation and Restoration of the Fathead Minnow Gut Microbiome after Low-Level Triclosan Exposure. Microbiome 2015, 3, 6. [CrossRef]

80. Zang, L.; Ma, Y.; Huang, W.; Ling, Y.; Sun, L.; Wang, X.; Zeng, A.; Dahlgren, R.A.; Wang, C.; Wang, H. Dietary Lactobacillus plantarum ST-III Alleviates the Toxic Effects of Triclosan on Zebrafish (Danio rerio) via Gut Microbiota Modulation. Fish Shellfish Immunol. 2019, 84, 1157-1169. [CrossRef]

81. Eggers, S.; Safdar, N.; Sethi, A.K.; Suen, G.; Peppard, P.E.; Kates, A.E.; Skarlupka, J.H.; Kanarek, M.; Malecki, K.M.C. Urinary Lead Concentration and Composition of the Adult Gut Microbiota in a Cross-Sectional Population-Based Sample. Environ. Int. 2019, 133, 105122. [CrossRef]

82. Wu, G.D.; Compher, C.; Chen, E.Z.; Smith, S.A.; Shah, R.D.; Bittinger, K.; Chehoud, C.; Albenberg, L.G.; Nessel, L.; Gilroy, E.; et al. Comparative Metabolomics in Vegans and Omnivores Reveal Constraints on Diet-Dependent Gut Microbiota Metabolite Production. Gut 2016, 65, 63-72. [CrossRef] [PubMed]

83. Yang, Y.; Yang, Y.S.H.; Lin, I.-H.; Chen, Y.; Lin, H.; Wu, C.; Su, Y.; Yang, Y.; Yang, S.; Suen, J. Phthalate Exposure Alters Gut Microbiota Composition and IgM Vaccine Response in Human Newborns. Food Chem. Toxicol. 2019, 132, 110700. [CrossRef] [PubMed]

84. Stanaway, I.B.; Wallace, J.C.; Shojaie, A.; Griffith, W.C.; Hong, S.; Wilder, C.S.; Green, F.H.; Tsai, J.; Knight, M.; Workman, T.; et al. Human Oral Buccal Microbiomes are Associated with Farmworker Status and Azinphos-Methyl Agricultural Pesticide Exposure. Appl. Environ. Microbiol. 2017, 83, e02149-16. [CrossRef] [PubMed]

85. Bever, C.S.; Rand, A.A.; Nording, M.; Taft, D.; Kalanetra, K.M.; Mills, D.A.; Breck, M.A.; Smilowitz, J.T.; German, J.B.; Hammock, B.D. Effects of Triclosan in Breast Milk on the Infant Fecal Microbiome. Chemosphere 2018, 203, 467-473. [CrossRef]

86. Ribado, J.V.; Ley, C.; Haggerty, T.D.; Tkachenko, E.; Bhatt, A.S.; Parsonnet, J. Household Triclosan and Triclocarban Effects on the Infant and Maternal Microbiome. EMBO Mol. Med. 2017, 9, 1732-1741. [CrossRef]

87. Knip, M.; Siljander, H. The Role of the Intestinal Microbiota in Type 1 Diabetes Mellitus. Nat. Rev. Endocrinol. 2016, 12, 154-167. [CrossRef]

88. De Goffau, M.C.; Fuentes, S.; van den Bogert, B.; Honkanen, H.; de Vos, W.M.; Welling, G.W.; Hyoty, H.; Harmsen, H.J.M. Aberrant Gut Microbiota Composition at the Onset of Type 1 Diabetes in Young Children. Diabetologia 2014, 57, 1569-1577. [CrossRef]

89. Krych, Ł.; Nielsen, D.; Hansen, A.; Hansen, C. Gut Microbial Markers are Associated with Diabetes Onset, Regulatory Imbalance, and IFN- $\Gamma$ Level in NOD Mice. Gut Microbes 2015, 6, 101-109. [CrossRef]

90. Chen, C.; You, L.; Huang, Q.; Fu, X.; Zhang, B.; Liu, R.; Li, C. Modulation of Gut Microbiota by Mulberry Fruit Polysaccharide Treatment of Obese Diabetic Db/Db Mice. Food Funct. 2018, 9, 3732-3742. [CrossRef]

91. Gulden, E.; Chao, C.; Tai, N.; Pearson, J.A.; Peng, J.; Majewska-Szczepanik, M.; Zhou, Z.; Wong, F.S.; Wen, L. TRIF Deficiency Protects Non-Obese Diabetic Mice from Type 1 Diabetes by Modulating the Gut Microbiota and Dendritic Cells. J. Autoimmun. 2018, 93, 57-65. [CrossRef]

92. Khokhlova, E.V.; Smeianov, V.V.; Efimov, B.A.; Kafarskaia, L.I.; Pavlova, S.I.; Shkoporov, A.N. Anti-inflammatory Properties of Intestinal Bifidobacterium Strains Isolated from Healthy Infants. Microbiol. Immunol. 2012, 56, 27-39. [CrossRef] [PubMed] 
93. Sweeney, T.E.; Morton, J.M. The Human Gut Microbiome A Review of the Effect of Obesity and Surgically Induced Weight Loss. JAMA Surg. 2013, 148, 563-569. [CrossRef] [PubMed]

94. Kaakoush, N.O. Insights into the Role of Erysipelotrichaceae in the Human Host. Front. Cell. Infect. Microbiol. 2015, 5, 84. [CrossRef] [PubMed]

95. De Theije, C.G.M.; Wopereis, H.; Ramadan, M.; van Eijndthoven, T.; Lambert, J.; Knol, J.; Garssen, J.; Kraneveld, A.D.; Oozeer, R. Altered Gut Microbiota and Activity in a Murine Model of Autism Spectrum Disorders. Brain Behav. Immun. 2014, 37, 197-206. [CrossRef]

96. Baxter, N.T.; Zackular, J.P.; Chen, G.Y.; Schloss, P.D. Structure of the Gut Microbiome Following Colonization with Human Feces Determines Colonic Tumor Burden. Microbiome 2014, 2, 20. [CrossRef]

97. Hidalgo-Cantabrana, C.; Lorena Ruiz, S.D.; Ruas-Madiedo, P.; Sanchez, B.; Margolles, A. Bifidobacteria and their Health-Promoting Effects. Microbiol. Spectr. 2017, 5. [CrossRef]

98. Zhang, L.; Day, A.; McKenzie, G.; Mitchell, H. Nongastric Helicobacter Species Detected in the Intestinal Tract of Children. J. Clin. Microbiol. 2006, 44, 2276-2279. [CrossRef]

99. Vandenberg, L.N.; Chahoud, I.; Heindel, J.J.; Padmanabhan, V.; Paumgartten, F.J.R.; Schoenfelder, G. Urinary, Circulating, and Tissue Biomonitoring Studies Indicate Widespread Exposure to Bisphenol A. Environ. Health Perspect. 2010, 118, 1055-1070. [CrossRef]

100. Birnbaum, L.S. When Environmental Chemicals Act Like Uncontrolled Medicine. Trends Endocrinol. Metab. 2013, 24, 321-323. [CrossRef]

101. Kim, K.; Kabir, E.; Jahan, S.A. Exposure to Pesticides and the Associated Human Health Effects. Sci. Total Environ. 2017, 575, 525-535. [CrossRef]

102. Zarean, M.; Poursafa, P. The Role of Environmental Disruptor Chemicals in the Development of Non Communicable Disease. Primordial Prev. Non Commun. Dis. 2019, 1121, 21-31.

103. European Food Safety Authority (EFSA). Conclusion regarding the Peer Review of the Pesticide Risk Assessment of the Active Substance Propamocarb. EFSA J. 2006, 78, 1-80.

104. Cho, I.; Blaser, M.J. The Human Microbiome: At the Interface of Health and Disease. Nat. Rev. Genet. 2012, 13, 260-270. [CrossRef] [PubMed]

105. Fernandez-Gonzalez, R.; Martinez-Carballo, E.; Gonzalez-Barreiro, C.; Rial-Otero, R.; Simal-Gandara, J. Distribution of Polychlorinated Biphenyls in both Products and by-Products of a Mussel Shell Incinerator Facility. Environ. Sci. Pollut. Res. 2011, 18, 1139-1146. [CrossRef]

106. Robson, M.; Melymuk, L.; Csiszar, S.A.; Giang, A.; Diamond, M.L.; Helm, P.A. Continuing Sources of PCBs: The Significance of Building Sealants. Environ. Int. 2010, 36, 506-513. [CrossRef]

107. Baker, N.A.; Shoemaker, R.; English, V.; Larian, N.; Sunkara, M.; Morris, A.J.; Walker, M.; Yiannikouris, F.; Cassis, L.A. Effects of Adipocyte Aryl Hydrocarbon Receptor Deficiency on PCB-Induced Disruption of Glucose Homeostasis in Lean and Obese Mice. Environ. Health Perspect. 2015, 123, 944-950. [CrossRef]

108. Mesnage, R.; Biserni, M.; Balu, S.; Frainay, C.; Poupin, N.; Jourdan, F.; Wozniak, E.; Xenakis, T.; Mein, C.A.; Antoniou, M.N. Integrated Transcriptomics and Metabolomics Reveal Signatures of Lipid Metabolism Dysregulation in HepaRG Liver Cells Exposed to PCB 126. Arch. Toxicol. 2018, 92, 2533-2547. [CrossRef]

109. Iszatt, N.; Janssen, S.; Lenters, V.; Dahl, C.; Stigum, H.; Knight, R.; Mandal, S.; Peddada, S.; Gonzalez, A.; Midtvedt, T.; et al. Environmental Toxicants in Breast Milk of Norwegian Mothers and Gut Bacteria Composition and Metabolites in their Infants at 1 Month. Microbiome 2019, 7, 34. [CrossRef]

110. Petriello, M.C.; Brandon, J.A.; Hoffman, J.; Wang, C.; Tripathi, H.; Abdel-Latif, A.; Ye, X.; Li, X.; Yang, L.; Lee, E.; et al. Dioxin-Like PCB 126 Increases Systemic Inflammation and Accelerates Atherosclerosis in Lean LDL Receptor-Deficient Mice. Toxicol. Sci. 2018, 162, 548-558. [CrossRef]

111. Mafra, D.; Lobo, J.C.; Barros, A.F.; Koppe, L.; Vaziri, N.D.; Fouque, D. Role of Altered Intestinal Microbiota in Systemic Inflammation and Cardiovascular Disease in Chronic Kidney Disease. Future Microbiol. 2014, 9 , 399-410. [CrossRef]

112. Janda, J.M.; Abbott, S.L. The Genus Aeromonas: Taxonomy, Pathogenicity, and Infection. Clin. Microbiol. Rev. 2010, 23, 35-73. [CrossRef] [PubMed]

113. Giulivo, M.; de Alda, M.L.; Capri, E.; Barcelo, D. Human Exposure to Endocrine Disrupting Compounds: Their Role in Reproductive Systems, Metabolic Syndrome and Breast Cancer. A Review. Environ. Res. 2016, 151, 251-264. [CrossRef] [PubMed]

114. Monneret, C. What is an Endocrine Disruptor? C. R. Biol. 2017, 340, 403-405. [CrossRef] [PubMed] 
115. Song, C.; Lin, J.; Huang, X.; Wu, Y.; Liu, J.; Wu, C. Effect of Butyl Paraben on the Development and Microbial Composition of Periphyton. Ecotoxicology 2016, 25, 342-349. [CrossRef]

116. Darbre, P.D. Endocrine Disruptors and Obesity. Curr. Obes. Rep. 2017, 6, 18-27. [CrossRef]

117. Fransway, A.F.; Fransway, P.J.; Belsito, D.V.; Yiannias, J.A. Paraben Toxicology. Dermatitis 2019, 30, $32-45$. [CrossRef]

118. Harley, K.G.; Berger, K.P.; Kogut, K.; Parra, K.; Lustig, R.H.; Greenspan, L.C.; Calafat, A.M.; Ye, X.; Eskenazi, B. Association of Phthalates, Parabens and Phenols found in Personal Care Products with Pubertal Timing in Girls and Boys. Hum. Reprod. 2019, 34, 109-117. [CrossRef]

119. Muscogiuri, G.; Barrea, L.; Laudisio, D.; Savastano, S.; Colao, A. Obesogenic Endocrine Disruptors and Obesity: Myths and Truths. Arch. Toxicol. 2017, 91,3469-3475. [CrossRef]

120. Teitelbaum, S.L.; Li, Q.; Lambertini, L.; Belpoggi, F.; Manservisi, F.; Falcioni, L.; Bua, L.; Silva, M.J.; Ye, X.; Calafat, A.M.; et al. Paired Serum and Urine Concentrations of Biomarkers of Diethyl Phthalate, Methyl Paraben, and Triclosan in Rats. Environ. Health Perspect. 2016, 124, 39-45. [CrossRef]

121. Amabebe, E.; Robert, F.O.; Agbalalah, T.; Orubu, E.S.F. Microbial Dysbiosis-Induced Obesity: Role of Gut Microbiota in Homoeostasis of Energy Metabolism. Br. J. Nutr. 2020, 123, 1127-1137. [CrossRef]

122. Indiani, C.M.D.S.P.; Rizzardi, K.F.; Castelo, P.M.; Caldas Ferraz, L.F.; Darrieux, M.; Parisotto, T.M. Childhood Obesity and Firmicutes/Bacteroidetes Ratio in the Gut Microbiota: A Systematic Review. Child. Obes. 2018, 14, 501-509. [CrossRef] [PubMed]

123. Hamm, A.K.; Manter, D.K.; Kirkwood, J.S.; Wolfe, L.M.; Cox-York, K.; Weir, T.L. The Effect of Hops (Humulus lupulus L.) Extract Supplementation on Weight Gain, Adiposity and Intestinal Function in Ovariectomized Mice. Nutrients 2019, 11, 3004. [CrossRef] [PubMed]

124. Kolatorova, L.; Lapcik, O.; Starka, L. Phytoestrogens and the Intestinal Microbiome. Physiol. Res. 2018, 67, S401-S408. [CrossRef] [PubMed]

125. Landete, J.M.; Arques, J.; Medina, M.; Gaya, P.; de Las Rivas, B.; Munoz, R. Bioactivation of Phytoestrogens: Intestinal Bacteria and Health. Crit. Rev. Food Sci. Nutr. 2016, 56, 1826-1843. [CrossRef] [PubMed]

126. Frankenfeld, C.L. O-Desmethylangolensin: The Importance of Equol's Lesser Known Cousin to Human Health. Adv. Nutr. 2011, 2, 317-324. [CrossRef] [PubMed]

127. Frankenfeld, C.L.; Atkinson, C.; Wahala, K.; Lampe, J.W. Obesity Prevalence in Relation to Gut Microbial Environments Capable of Producing Equol or O-Desmethylangolensin from the Isoflavone Daidzein. Eur. J. Clin. Nutr. 2014, 68, 526-530. [CrossRef]

128. Candela, M.; Biagi, E.; Soverini, M.; Consolandi, C.; Quercia, S.; Severgnini, M.; Peano, C.; Turroni, S.; Rampelli, S.; Pozzilli, P.; et al. Modulation of Gut Microbiota Dysbioses in Type 2 Diabetic Patients by Macrobiotic Ma-Pi 2 Diet. Br. J. Nutr. 2016, 116, 80-93. [CrossRef]

129. Everard, A.; Belzer, C.; Geurts, L.; Ouwerkerk, J.P.; Druart, C.; Bindels, L.B.; Guiot, Y.; Derrien, M.; Muccioli, G.G.; Delzenne, N.M.; et al. Cross-Talk between Akkermansia Muciniphila and Intestinal Epithelium Controls Diet-Induced Obesity. Proc. Natl. Acad. Sci. USA 2013, 110, 9066-9071. [CrossRef]

130. Oki, K.; Toyama, M.; Banno, T.; Chonan, O.; Benno, Y.; Watanabe, K. Comprehensive Analysis of the Fecal Microbiota of Healthy Japanese Adults Reveals a New Bacterial Lineage Associated with a Phenotype Characterized by a High Frequency of Bowel Movements and a Lean Body Type. BMC Microbiol. 2016, 16, 284. [CrossRef]

131. Zhan, X.; Stamova, B.; Jin, L.; DeCarli, C.; Phinney, B.; Sharp, F.R. Gram-Negative Bacterial Molecules Associate with Alzheimer Disease Pathology. Neurology 2016, 87, 2324-2332. [CrossRef]

132. Strotmeyer, E.S.; Yang, Z.; LaPorte, R.E.; Chang, Y.F.; Steenkiste, A.R.; Pietropaolo, M.; Nucci, A.M.; Shen, S.X.; Wang, L.M.; Wang, B.Y.; et al. Infant Diet and Type 1 Diabetes in China. Diabetes Res. Clin. Pract. 2004, 65, 283-292. [CrossRef] [PubMed]

133. Zhang, J.; Yang, Y.; Liu, W.; Liu, J. Potential Endocrine-Disrupting Effects of Metals via Interference with Glucocorticoid and Mineralocorticoid Receptors. Environ. Pollut. 2018, 242, 12-18. [CrossRef] [PubMed]

134. Planchart, A.; Green, A.; Hoyo, C.; Mattingly, C.J. Heavy Metal Exposure and Metabolic Syndrome: Evidence from Human and Model System Studies. Curr. Environ. Health Rep. 2018, 5, 110-124. [CrossRef] [PubMed]

135. Wang, G.; DiBari, J.; Bind, E.; Steffens, A.M.; Mukherjee, J.; Bartell, T.R.; Bellinger, D.C.; Hong, X.; Ji, Y.; Wang, M.; et al. In Utero Exposure to Mercury and Childhood Overweight or Obesity: Counteracting Effect of Maternal Folate Status. BMC Med. 2019, 17, 216. [CrossRef] [PubMed] 
136. Tinkov, A.A.; Filippini, T.; Ajsuvakova, O.P.; Aaseth, J.; Gluhcheva, Y.G.; Ivanova, J.M.; Bjorklund, G.; Skalnaya, M.G.; Gatiatulina, E.R.; Popova, E.V.; et al. The Role of Cadmium in Obesity and Diabetes. Sci. Total Environ. 2017, 601, 741-755. [CrossRef]

137. Wang, X.; Gao, D.; Zhang, G.; Zhang, X.; Li, Q.; Gao, Q.; Chen, R.; Xu, S.; Huang, L.; Zhang, Y.; et al. Exposure to Multiple Metals in Early Pregnancy and Gestational Diabetes Mellitus: A Prospective Cohort Study. Environ. Int. 2020, 135, 105370. [CrossRef]

138. Paul, D.S.; Walton, F.S.; Saunders, R.J.; Styblo, M. Characterization of the Impaired Glucose Homeostasis Produced in C57BL/6 Mice by Chronic Exposure to Arsenic and High-Fat Diet. Environ. Health Perspect. 2011, 119, 1104-1109. [CrossRef]

139. Sikalidis, A.K.; Maykish, A. The Gut Microbiome and Type 2 Diabetes Mellitus: Discussing a Complex Relationship. Biomedicines 2020, 8, 8. [CrossRef]

140. European Food Safety Authority (EFSA). Statement on Tolerable Weekly Intake for Cadmium. EFSA J. 2011, 9, 1975.

141. Halden, R.U.; Lindeman, A.E.; Aiello, A.E.; Andrews, D.; Arnold, W.A.; Fair, P.; Fuoco, R.E.; Geer, L.A.; Johnson, P.I.; Lohmann, R.; et al. The Florence Statement on Triclosan and Triclocarban. Environ. Health Perspect. 2017, 125, 064501. [CrossRef]

142. Alvarez-Munoz, D.; Rodriguez-Mozaz, S.; Jacobs, S.; Serra-Compte, A.; Caceres, N.; Sioen, I.; Verbeke, W.; Barbosa, V.; Ferrari, F.; Fernandez-Tejedor, M.; et al. Pharmaceuticals and Endocrine Disruptors in Raw and Cooked Seafood from European Market: Concentrations and Human Exposure Levels. Environ. Int. 2018, 119, 570-581. [CrossRef] [PubMed]

143. Alvarez-Munoz, D.; Rambla-Alegre, M.; Carrasco, N.; Lopez de Alda, M.; Barcelo, D. Fast Analysis of Relevant Contaminants Mixture in Commercial Shellfish. Talanta 2019, 205, 119884. [CrossRef] [PubMed]

144. Kalloo, G.; Calafat, A.M.; Chen, A.; Yolton, K.; Lanphear, B.P.; Braun, J.M. Early Life Triclosan Exposure and Child Adiposity at 8 Years of Age: A Prospective Cohort Study. Environ. Health 2018, 17, 24. [CrossRef] [PubMed]

145. Xie, X.; Lu, C.; Wu, M.; Liang, J.; Ying, Y.; Liu, K.; Huang, X.; Zheng, S.; Du, X.; Liu, D.; et al. Association between Triclocarban and Triclosan Exposures and the Risks of Type 2 Diabetes Mellitus and Impaired Glucose Tolerance in the National Health and Nutrition Examination Survey (NHANES 2013-2014). Environ. Int. 2020, 136, 105445. [CrossRef] [PubMed]

146. Schebb, N.H.; Ahn, K.C.; Dong, H.; Gee, S.J.; Hammock, B.D. Whole Blood is the Sample Matrix of Choice for Monitoring Systemic Triclocarban Levels. Chemosphere 2012, 87, 825-827. [CrossRef] [PubMed]

147. Plovier, H.; Everard, A.; Druart, C.; Depommier, C.; Van Hul, M.; Geurts, L.; Chilloux, J.; Ottman, N.; Duparc, T.; Lichtenstein, L.; et al. A Purified Membrane Protein from Akkermansia Muciniphila or the Pasteurized Bacterium Improves Metabolism in Obese and Diabetic Mice. Nat. Med. 2017, 23, 107-113. [CrossRef] [PubMed]

148. Shin, N.; Whon, T.W.; Bae, J. Proteobacteria: Microbial Signature of Dysbiosis in Gut Microbiota. Trends Biotechnol. 2015, 33, 496-503. [CrossRef]

149. Pacyga, D.C.; Sathyanarayana, S.; Strakovsky, R.S. Dietary Predictors of Phthalate and Bisphenol Exposures in Pregnant Women. Adv. Nutr. 2019, 10, 803-815. [CrossRef]

150. Milosevic, N.; Milanovic, M.; Sudji, J.; Zivanovic, D.B.; Stojanoski, S.; Vukovic, B.; Milic, N.; Stojanoska, M.M. Could Phthalates Exposure Contribute to the Development of Metabolic Syndrome and Liver Disease in Humans? Environ. Sci. Pollut. Res. 2020, 27, 772-784. [CrossRef] 
151. Martinez-Ibarra, A.; Daniel Martinez-Razo, L.; Ricardo Vazquez-Martinez, E.; Martinez-Cruz, N.; Flores-Ramirez, R.; Garcia-Gomez, E.; Lopez-Lopez, M.; Ortega-Gonzalez, C.; Camacho-Arroyo, I.; Cerbon, M. Unhealthy Levels of Phthalates and Bisphenol A in Mexican Pregnant Women with Gestational Diabetes and its Association to Altered Expression of miRNAs Involved with Metabolic Disease. Int. J. Mol. Sci. 2019, 20, 3343. [CrossRef]

152. Pannaraj, P.S.; Li, F.; Cerini, C.; Bender, J.; Yang, S.; Rollie, A.; Adisetiyo, H.; Zabih, S.; Lincez, P.J.; Bittinger, K.; et al. Association between Breast Milk Bacterial Communities and Establishment and Development of the Infant Gut Microbiome. JAMA Pediatrics 2017, 171, 647-654. [CrossRef] [PubMed]

(C) 2020 by the authors. Licensee MDPI, Basel, Switzerland. This article is an open access article distributed under the terms and conditions of the Creative Commons Attribution (CC BY) license (http://creativecommons.org/licenses/by/4.0/). 